\title{
Original paper \\ Petrogenesis of the Late Carboniferous Sagsai Pluton in the SE Mongolian Altai
}

\author{
David BURIÁNEK ${ }^{1 *}$, Vojtěch JANOUŠEK ${ }^{1}$, Pavel HANŽL¹ ${ }^{1}$ Yingde JIANG², Karel SCHULMANN ${ }^{13}$, \\ Ondrej LEXA ${ }^{4}$, Battushig ALTANBAATAR ${ }^{5}$
}

${ }^{1}$ Czech Geological Survey, Klárov 3, 11821 Prague 1, Czech Republic; david.burianek@geology.cz

2 State Key Laboratory of Isotope Geochemistry, Guangzhou Institute of Geochemistry, Chinese Academy of Sciences, Guangzhou 510640, China

${ }^{3}$ Ecole et Observatoire des Sciences de la Terre, Université de Strasbourg, UMR 7516 of CNRS, 1 rue Blessig, 67084 Strasbourg Cedex, France

${ }^{4}$ Institute of Petrology and Structural Geology, Charles University in Prague, Albertov 6, 12843 Prague 2, Czech Republic

${ }^{5}$ Institute of Paleontology and Geology, Mongolian Academy of Sciences, Ulaanbaatar 15160, Mongolia

*Corresponding author

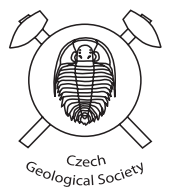

Sagsai Pluton intruded the low-grade metavolcanosedimentary complex of the Cambrian Tugrug Fm. in the Sagsai river valley SW of Tsogt soum, Gobi-Altai aimag (SE Mongolian Altai). This oval body $(\sim 9 \times 12 \mathrm{~km})$ is composed mainly of amphibole monzogabbros to quartz diorites, biotite to amphibole-biotite syenites to quartz monzonites. It is intruded by anatectic two-mica granites along the $\mathrm{W}$ rim. The abundant mafic microgranular enclaves enclosed by syenites to quartz monzonites are interpreted as an evidence of vigorous magma mingling and mixing. The newly obtained LA ICP-MS zircon ages for two samples of quartz monzonites gave emplacement ages of $307 \pm 1 \mathrm{Ma}$ and $309 \pm 2 \mathrm{Ma}(2 \sigma)$, respectively. The zircons highly have $\varepsilon_{H f}^{t}$ values varying broadly from +2.4 to +11.6 ruling out a participation of an old, mature crust. One gabbro body gave zircon $\mathrm{U}-\mathrm{Pb}$ age of $322 \pm 2 \mathrm{Ma}$ with positive $\varepsilon_{\mathrm{Hf}}^{t}$ values of +7.4 to +11.5 . The latter suggest an exclusively juvenile, depleted mantle-derived magma source. According to calculated P-T conditions, we propose three main stages in the Sagsai Pluton evolution. The gabbro started to grow at $>1000^{\circ} \mathrm{C}$ and $0.8-0.9 \mathrm{GPa}$. The ensuing magma mixing with crustal melts and final crystallization of gabbro occurred at similar $\mathrm{P}-\mathrm{T}$ conditions (740-830 ${ }^{\circ} \mathrm{C}$ and $0.5-0.6 \mathrm{GPa}$ ) as partial melting of migmatite xenoliths in the Sagsai Pluton. The P-T conditions of the Sagsai Pluton final emplacement calculated from quartz syenite (c. 600 to $670^{\circ} \mathrm{C}$ and $\left.0.4-0.5 \mathrm{GPa}\right)$ are consistent with the mineral assemblage in the contact aureole (cordierite-biotite and biotite-chlorite schists). The magmatic evolution of Sagsai Pluton confirms a model of deep lithosphere thermal anomaly associated with heterogeneous melting of crust in a post-subduction extensional regime, perhaps shortly after the slab break-off.

Keywords: Central Asian Orogenic Belt, Lake Zone, alkaline Pluton, U-Pb zircon dating, geochemistry

Received: 16 October, 2015; accepted: 24 January, 2016; handling editor: O. Gerel

The online version of this article (doi: 10.3190/jgeosci.207) contains supplementary electronic material.

\section{Introduction}

The Central Asian Orogenic Belt (CAOB) is an accretionary Phanerozoic orogen situated between the Siberian Craton to the north and the North China and Tarim cratons to the south (Hendrix et al. 1992; Şengör et al. 1993; Dergunov 2001; Jahn 2004; Windley et al. 2007). Multiple geotectonic processes were responsible for its complicated evolution and final architecture (e. g. Badarch et al. 2002; Windley et al. 2007).

The central part of the CAOB is well exposed in the SW Mongolia, where it includes Mid- to Late Palaeozoic island arcs, ophiolite mélanges and Late Carboniferous to Permian magmatic rocks (Badarch et al. 2002). Suturing in the southern part of the CAOB proceeded eastwards from the latest Palaeozoic in the Tien Shan to the Triassic in Inner Mongolia (Xixi et al. 1990; Xiao et al. 2004,
2008). It was accompanied by vigorous magmatic activity in the terranes accreted to the southern margin of the Siberian Craton (Zhu et al. 2001; Zhang X et al. 2008; Jahn et al. 2009). Formation of Late Palaeozoic igneous rocks was dominantly related with the final closure of the Palaeo Asian Ocean (Xiao et al. 2003; Kröner et al. 2007; Windley et al. 2007); however, some granitoids have post-collisional, or even anorogenic, features (e. g. Hong et al. 1995; Wu et al. 2002; Shi et al. 2004; Mao et al. 2014)

The Late Palaeozoic to Early Mesozoic magmatic activity in Mongolia was contemporaneous with the final stages of the CAOB consolidation (e. g. Xiao et al. 2003; Zhang $X$ et al. 2008, 2011). Although many plutons and batholiths belong to the calc-alkaline series and have I-type characteristics, the proportion of alkaline granites is remarkable (Jahn et al. 2000). Yarmolyuk and 

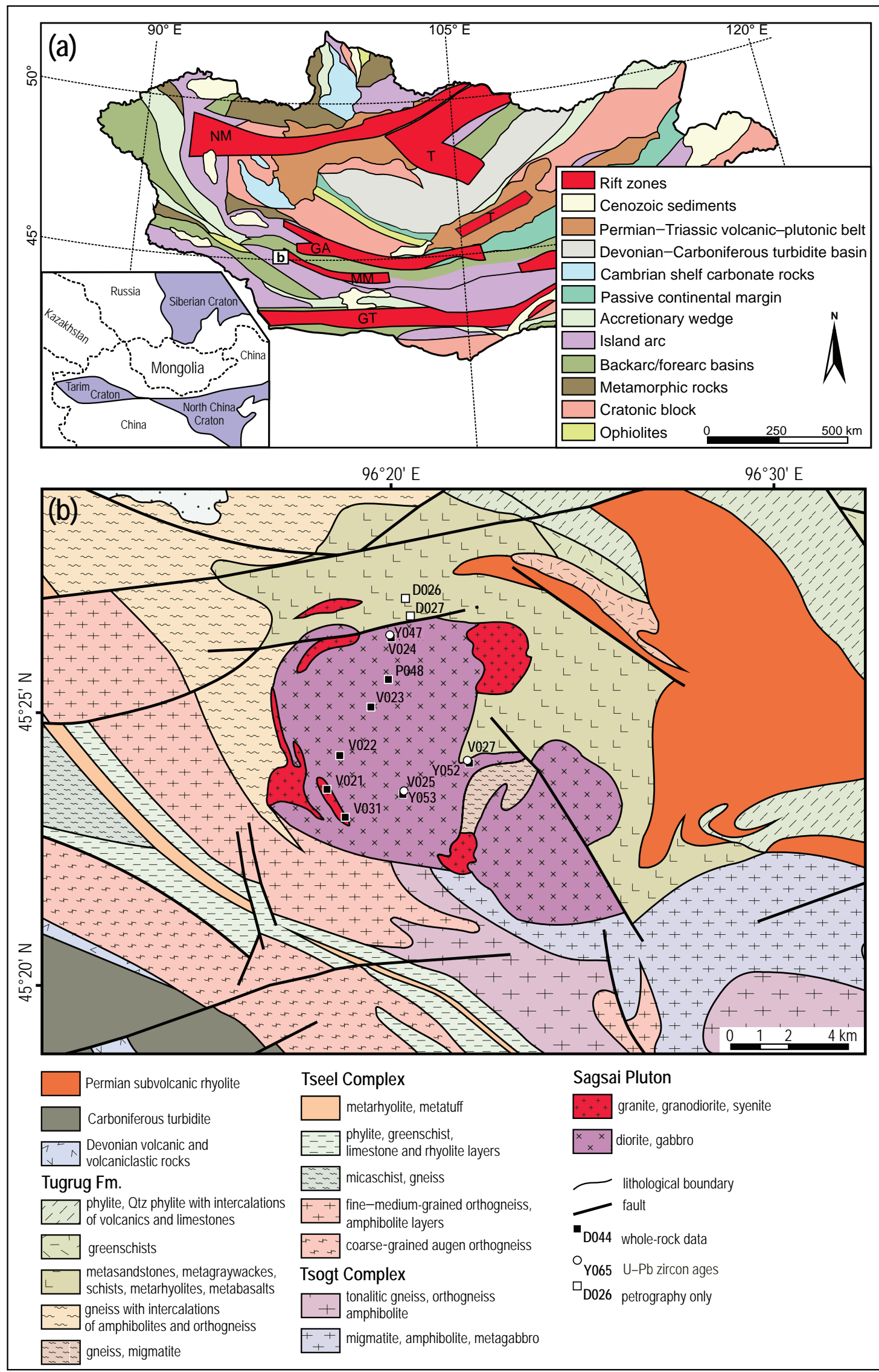
Tab. 1 List of the studied samples

\begin{tabular}{|c|c|c|c|c|c|c|c|}
\hline Name & Lon & Lat & Rock name & $\mathrm{Sr}-\mathrm{Nd}$ & Zrn & WR & Remark \\
\hline D026 & 96,34286 & 45,46066 & spotted schist & & & & up to $1 \mathrm{~m}$ thick layers of metapelite alternating with quartzite \\
\hline D027b & 96,34320 & 45,45370 & Cdr-Bt schist & & & & up to $2 \mathrm{~m}$ thick layers of metapelite alternating with quartzite \\
\hline P048a & 96,33478 & 45,43095 & Bt syenite & & & + & up to several $\mathrm{m}$ long xenoliths of Grt-Bt migmatite in syenite \\
\hline P048b & 96,33478 & 45,43095 & Grt-Bt migmatite & & & & country-rock xenolith \\
\hline V021 & 96,31001 & 45,39695 & Ms-Bt granite & + & & + & contact of monzonites with coarse-grained $\mathrm{Bt}$ granites \\
\hline V022 & 96,31481 & 45,40710 & Bt-Amp gabbro & + & & + & medium-grained \\
\hline V023 & 96,32758 & 45,42225 & Amp-Bt microdiorite & + & & + & dyke up to $1.5 \mathrm{~m}$ thick, $\mathrm{P}-\mathrm{T}$ calculation \\
\hline V024a & 96,33536 & 45,44375 & Bt-Amp monzogabbro & + & + & + & same rock as sample Y047 (P-T calculation) \\
\hline V024b & 96,33536 & 45,44375 & Bt-Amp monzonite & + & & + & contact with Bt-Amp monzogabbro \\
\hline V025 & 96,34271 & 45,39595 & Bt granodiorite & & + & + & same rock as sample Y053 \\
\hline V027c & 96,37103 & 45,40620 & $\mathrm{Bt}-\mathrm{Amp}$ monzonite & & & & MME (P-T calculation) \\
\hline V027a & 96,37103 & 45,40620 & Amp microgabbro & + & & + & dyke up to $1 \mathrm{~m}$ thick \\
\hline V027b & 96,37103 & 45,40620 & Amp-Bt syenite & & + & + & same rock as sample $\mathrm{Y} 052, \mathrm{P}-\mathrm{T}$ calculation \\
\hline V031 & 96,31799 & 45,38826 & Ms-Bt granite & & & + & granite dyke up to $30 \mathrm{~m}$ thick \\
\hline
\end{tabular}

Thin-sections of all the samples listed were studied petrographically. MME = mafic microgranular enclave. Types of additional analyses:

$\mathrm{Sr}-\mathrm{Nd}=\mathrm{Sr}-\mathrm{Nd}$ isotopic data; $\mathrm{Zrn}=$ zircon geochronology and Hf isotopic composition; WR = whole-rock geochemistry

Kovalenko $(1991,2001)$ assumed an existence of five linear E-W trending systems in Mongolian part of the $\mathrm{CAOB}$ connected to the alkaline magmatic affinity. These systems controlled by regional-scale faults related to Late Palaeozoic igneous bimodal associations have been interpreted as parts of the Late Palaeozoic Asian rift system (Yarmolyuk 1983; Kovalenko and Chernov 2008). From south to north, they comprise: Gobi-Tien Shan, Main Mongolian Lineament, Gobi-Altai, North Mongolian and North Mongolian-Transbaikalian (Fig. 1a).

The alkaline granite massifs in the SW Mongolia coincide with Gobi-Altai, Main Mongolian Lineament and the Gobi-Tien Shan rift zones (Kovalenko and Chernov 2008) which are spatially related with major tectonic boundaries between Precambrian blocks (Kozlovsky et al. 2015). The formation of the Main Mongolian Lineament and the Gobi-Tien Shan rift zones corresponded to early evolution of this rift system (Kuzmin et al. 2011). Recent geophysical study (Guy et al. 2014a, 2015) showed that the presumed rift systems coincide with intense magnetic lineaments suggesting existence of deep-seated tectonomagmatic zones. These zones are probably connected to a giant source located deep in the mantle as indicated by the gravity signal.

The main aim of this paper is to constrain the petrology, geochemistry, likely petrogenesis and temporal evolution of the newly recognized latest Carboniferous, mainly mafic Sagsai Pluton situated at the western termination of the Main Mongolian Lineament (Fig. 1b).

\footnotetext{
৫

Fig. 1 Position of the Sagsai Pluton in the Mongolia. a - Distribution of Late Paleozoic and Early Cretaceous rift zones in Mongolia (according to Chernov and Kovalenko 2008): GT - Gobi-Tien Shan, MM - Main Mongolian Lineament, GA - Gobi-Altai, NM - North Mongolian, $\mathrm{T}$ - North Mongolian-Transbaikal rifts. Geotectonic map of western Mongolia (modified from Badarch et al. 2002). b - Geological map of the Sagsai Pluton.
}

\section{Geological setting}

Numerous occurrences of Late Carboniferous to Early Permian alkaline magmatic bodies have been described from the Gobi-Tien Shan Rift Zone. For example, bimodal volcanic association of the Noyon and Tost ranges accompanied by peralkaline granites was formed about $318 \mathrm{Ma}$ ago (Yarmolyuk et al. 2005). The Khan Bogd Massif in the southern Gobi is Early Permian (e.g. Sandimirova et al. 1980; Vladykin et al. 1981; Kovalenko et al. 2006). Alkaline signatures were described in the Permian post-tectonic plutons along the Trans-Altai shear zones and some such magmatic rocks form the Gobi-Tien Shan Batholith (Hanžl et al. 2008) and Tsagaan Bogd Massif (Kozlovsky et al 2012). Granitic massifs related to the Gobi-Altai Rift Zone are predominantly Early Permian (e.g. Shar Oroy Massif dated at $285 \pm 1 \mathrm{Ma}$; Buriánek et al. 2012); Zuun-Bogd, Serkh-Uul, Ulaan-Uul and KharUzuur massifs were emplaced from $293 \pm 1$ to $279 \pm 1 \mathrm{Ma}$ (Kozlovsky et al 2015).

The Sagsai Pluton is located $\sim 40 \mathrm{~km}$ southeast of Tseel soum in the Govi-Altai Province (SW Mongolia). This ellipsoidal body is about $12 \mathrm{~km}$ long in the $\mathrm{E}-\mathrm{W}$ direction and $9 \mathrm{~km}$ wide (Fig. 1b) and is best exposed in valleys of the Sagsai river and its left tributaries. Sagsai Pluton is composed mainly (Tab. 1) of amphibole monzogabbros to quartz diorites (Fig. 2a-b), biotite to amphibole-biotite syenites to quartz monzonites, and two-mica granites (Fig. 2c-d).

The pluton intruded mostly into the Lower Palaeozoic volcano-sedimentary complex (Tugrug Fm.: Rauzer et al. 1987; Dergunov 2001). Contact with the fine-grained orthogneiss of the Tseel metamorphic complex in the $\mathrm{SW}$ is obscured. Light grey anatectic muscovite-biotite granites rim the endocontact of the pluton. Large screens of migmatitic gneiss to migmatite and cordierite hornfels 

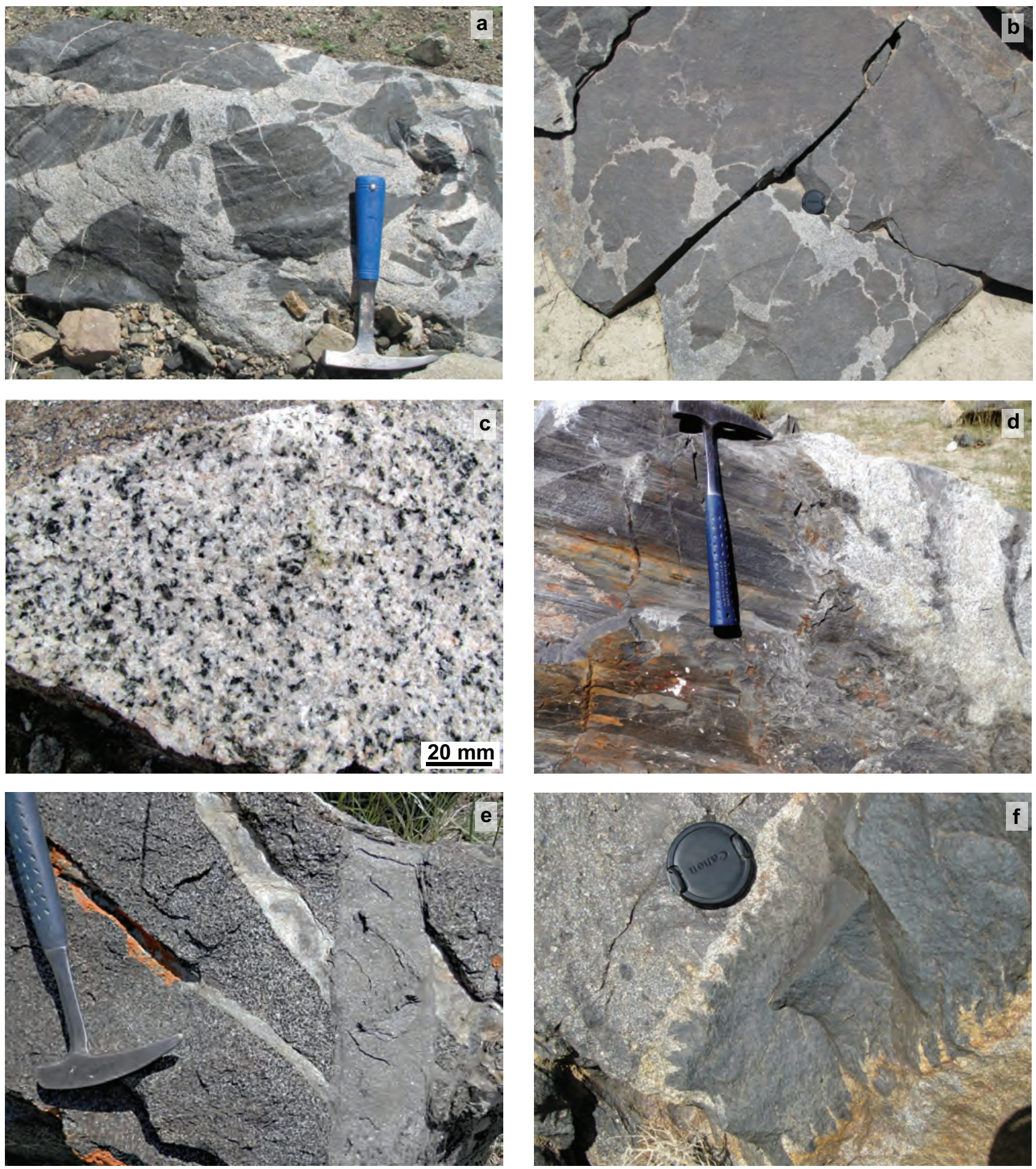

Fig. 2 Field photographs from the Sagsai Pluton. a - Cumulate gabbro enclaves in the monzonite (sample location V021). The hammer shaft is $\sim 27 \mathrm{~cm}$ long. $\mathbf{b}$ - Mingling between monzonite and gabbro produces MME with irregular shape and net-veining (sample location V027). Diameter of the camera lens cap is $\sim 5 \mathrm{~cm}$. c - Muscovite-biotite granite (documentation point V031). d - Contact of muscovite-biotite granite with cordierite hornfels (documentation point D029). The hammer shaft is $\sim 32 \mathrm{~cm}$ long. e - Two generations of dykes crosscutting medium-grained amphibole gabbro. Thin aplite dykes are older than the microgabbro dyke (sample location D028). The hammer shaft is $\sim 32 \mathrm{~cm}$ long. $\mathbf{f}-\mathrm{Granite}$ melt resulting from partial melting of metapsammite by a mafic dyke (documentation point V026). Diameter of the camera lens cap is $\sim 5 \mathrm{~cm}$.

are common in the pluton's roof. The abundant mafic microgranular enclaves (MME) and cumulate gabbro enclaves enclosed by syenites to quartz monzonites vary between 0.01 to $4.5 \mathrm{~m}$ in size and have various shapes (Fig. 2a-b). Common are younger aplite, microdiorite and microgabbro dykes up to $2 \mathrm{~m}$ thick with sharp contacts 
against the surrounding syenite and/or gabbro (Fig. 2e). Some mafic dykes in the metasedimentary wall rocks are rimmed by in-situ formed granitic melt (Fig. 2f).

The contact aureole is visible only in weakly metamorphosed sediments (siltstone and greywacke) of Tugrug Fm. and its width varies from $500 \mathrm{~m}$ to $1000 \mathrm{~m}$ (Tab. 1). Fine- to medium-grained cordierite hornfelses, spotted and chlorite schists within the contact aureole are usually slightly deformed, and sedimentary bedding is often preserved. The spots and cordierite porphyroblasts occur in well-defined argillitic layers, interbedded with metagreywackes, metatuffs and metavolcanites.

\section{Analytical methods}

\subsection{Whole-rock geochemistry}

Whole-rock analyses were performed in ActLabs (Vancouver, Canada) using the 4Lithoresearch procedure (http://www.actlabs.com). Major-element concentrations were obtained by Inductively-Coupled Plasma Optical Emission Spectrometry (ICP-OES), trace-element concentrations by Inductively-Coupled Plasma Mass Spectrometry (ICP-MS) following a lithium metaborate/ tetraborate fusion and weak nitric acid dissolution. Such a procedure ensures that the entire sample is digested, including the refractory phases such as zircon or sphene. The geochemical data were plotted and recalculated using the GCDkit software (Janoušek et al. 2006).

\subsection{Mineral chemistry}

Electron-microprobe analyses (EMPA) were performed by P. Gadas using the Cameca SX-100 instrument at the Joint Laboratory of Electron Microscopy and Microanalysis of Masaryk University and the Czech Geological Survey (Brno, Czech Republic). The measurements were carried out using a wave-dispersion mode under the following conditions: accelerating voltage of $15 \mathrm{kV}$, beam current of $10 \mathrm{nA}$ and beam diameter of $5 \mu \mathrm{m}$. Natural and synthetic standards were used $(\mathrm{Si}, \mathrm{Al}$ - sanidine, $\mathrm{Mg}$ - olivine, $\mathrm{Fe}$ - almandine, $\mathrm{Ca}$ - andradite, $\mathrm{Mn}$ - rhodonite, $\mathrm{Ti}$ - Ti-hornblende, $\mathrm{Cr}$ - chromite, $\mathrm{Na}$ - albite, $\mathrm{K}$ - orthoclase, $\mathrm{P}$ - apatite, $\mathrm{F}$ - topaz, $\mathrm{Cl}, \mathrm{V}$ - vanadinite, $\mathrm{Zn}$ - gahnite, $\mathrm{Cu}$ - metallic $\mathrm{Cu}, \mathrm{Y}-\mathrm{YAG})$. The raw concentration data were corrected using the method of Pouchou and Pichoir (1985).

The empirical formulae of feldspars and micas were recalculated to 8 and 22 oxygen atoms, respectively. The amphibole formulae were obtained on the basis of 23 oxygen atoms (Leake et al. 1997). The $\mathrm{Fe}^{2+} / \mathrm{Fe}^{3+}$ ratios in amphiboles were estimated assuming the cation sum of 13 without $\mathrm{Ca}, \mathrm{Na}$ and $\mathrm{K}$ (13 eCNK). Pyroxenes have been classified according to Morimoto et al. (1988); the formulae were obtained on the basis of 4 cations and the ferric iron estimated after Droop (1987). Representative electron-microprobe analyses of amphibole, feldspars and biotite from the Sagsai Pluton ale given in the Electronic Supplementary Materials 1-3. The abbreviations of the mineral names used in the text are taken from Whitney and Evans (2010).

\subsection{Thermobarometry}

Temperature, pressure and $\mathrm{fO}_{2}$ estimates in the igneous rocks are based predominantly on the thermobarometric formulations empirically derived by Ridolfi et al. (2010) and Ridolfi and Renzulli (2012). In addition, total Al content of amphibole rims (amphibole geobarometry; Anderson and Smith 1995) together with amphibole-plagioclase geothermometer (Holland and Blundy 1994) were used to calculate pressure and solidus temperature. The $\mathrm{P}-\mathrm{T}$ conditions of partial melting for migmatite xenolith were assessed with THERMOCALC 3.33 (Holland and Powell 1998; Powell and Holland 2008) in the average $\mathrm{P}-\mathrm{T}$ mode. This method is based on the calculation of an independent set of reactions between the mineral phases of an equilibrium assemblage and calculates the average $\mathrm{P}-\mathrm{T}$ from the intersection of all these reactions. Activities of the mineral phases used for the calculations were obtained by the AX software (Holland and Powell 1998).

In order to constrain the metamorphic temperatures in the contact aureole Sagsai Pluton, the Ti content in biotite (Henry et al. 2005) was employed. This geothermometer was calibrated for graphitic metapelites that contain ilmenite or rutile as a Ti-saturating phase.

\subsection{U-Pb geochronology}

Zircons were separated using heavy liquid and magnetic techniques, and then purified by handpicking under a binocular microscope. Zircon grains $>50 \mu \mathrm{m}$ were selected, mounted in epoxy resin and then polished. Cathodoluminescence (CL) imaging was done on CAMECA SX-100 electron microprobe equipped with a Mono CL3 detector at the Institute of Petrology and Structural Geology, Charles University in Prague. Zircon dating used an ArF excimer $193 \mathrm{~nm}$ laser ablation system (Resolution M-50) coupled with a Nu Plasma HR MC-ICP-MS at the Department of Earth Sciences of the University of Hong Kong, following the analytical procedure described by Xia et al. (2011). Most analyses were carried out with a beam diameter of $40 \mu \mathrm{m}, 5 \mathrm{~Hz}$ repetition rate and energy of $\sim 5 \mathrm{~J} / \mathrm{cm}^{2}$ per pulse. Zircon standard 91500 was used for calibration. The mass fractionation correction and isotopic results were calculated by ICPMSDataCal (version 7.0, Liu et al. 2008). The age calculations and concordia 
plots were done using ISOPLOT (version 3.7, Ludwig 2003). Individual analyses are presented with $1 \sigma$ error in concordia diagrams, and uncertainties in mean age calculations are quoted at the $95 \%$ level $(2 \sigma) .{ }^{206} \mathrm{~Pb} /{ }^{238} \mathrm{U}$ ages are used for grains younger than $1.0 \mathrm{Ga}$, and ${ }^{207} \mathrm{~Pb} /{ }^{206} \mathrm{~Pb}$ ages older ones. The complete LA-ICP-MS analytical data for dated zircons from the Sagsai Pluton are given in the Electronic Supplementary Material 4.

\subsection{Hafnium isotopes}

Zircon $\mathrm{Lu}-\mathrm{Hf}$ isotopic analyses were carried out by Neptune Plus multi-collector ICP-MS equipped with a Resolution M-50 laser-ablation system at Guangzhou Institute of Geochemistry, Chinese Academy of Science. The measurements were conducted on selected large dated zircon grains, with a beam diameter of $45 \mu \mathrm{m}, 8 \mathrm{~Hz}$ repetition rate, and energy of $80 \mathrm{~mJ}$. Helium was used as carrier gas and some nitrogen was added in gas line to enhance the sample signal. The signal collection mode was one block with 200 cycles for each analysis, which consisted of 30 s gas blank collection and 30s laser ablation. Isobaric interference of ${ }^{176} \mathrm{Lu}$ on ${ }^{176} \mathrm{Hf}$ was corrected by using a recommended ${ }^{176} \mathrm{Lu} /{ }^{175} \mathrm{Lu}$ ratio of 0.02655 (Machado and Simonetti 2001). Interference of ${ }^{176} \mathrm{Yb}$ on ${ }^{176} \mathrm{Hf}$ was corrected for by using mass bias obtained on line and assuming ${ }^{176} \mathrm{Yb} /{ }^{172} \mathrm{Yb}=0.5887$ (Wu et al. 2006). Penglai zircon was measured as the reference material ( $\mathrm{Li}$ et al. 2010). All Hf isotope data are calculated with the decay constant of $1.867 \times 10^{-11} \mathrm{yr}^{-1}$ (Söderlund et al. 2004). The chondritic values of ${ }^{176} \mathrm{Hf} /{ }^{177} \mathrm{Hf}=0.0332$ and ${ }^{176} \mathrm{Lu} /{ }^{177} \mathrm{Hf}$ $=0.282772$ reported by Blichert-Toft et al. (1997) were employed for the calculation of $\varepsilon_{H f}^{t}$ values. The depletedmantle evolution line is defined by present-day ${ }^{176} \mathrm{Hf} /{ }^{177} \mathrm{Hf}$ of 0.28325 and ${ }^{176} \mathrm{Lu} /{ }^{177} \mathrm{Hf}$ of 0.0384 (Griffin et al. 2004). Because zircons were formed in granitic magma derived from felsic crust, a "crustal" model age $\left(T_{D M}^{C}\right)$ is considered more meaningful (Griffin et al. 2004). In present work, this model age $\left(T_{D M}^{C}\right)$ was calculated for each zircon grain, assuming the mean ${ }^{176} \mathrm{Lu} /{ }^{177} \mathrm{Hf}$ ratio of 0.0093 for the upper continental crust (Amelin et al. 1999). The Hf isotopic data are listed in Tab. 3.

\section{6. $\mathrm{Sr}-\mathrm{Nd}$ isotopes}

For the radiogenic isotope determinations, samples were dissolved using a combined $\mathrm{HF}-\mathrm{HCl}-\mathrm{HNO}_{3}$ digestion. Strontium and REE were isolated from the bulk matrix by the column chromatography techniques using TRU and $\mathrm{Sr}$ resins by Triskem Int. (Pin et al. 1994). The Nd was further separated from the REE fraction with Ln resin (Pin and Zalduegui 1997). Further analytical details were reported by Míková and Denková (2007). Isotopic analyses of $\mathrm{Sr}$ and $\mathrm{Nd}$ were performed on a Finnigan
MAT 262 thermal ionization mass spectrometer housed at the Czech Geological Survey in dynamic mode using a single $\mathrm{Ta}$ filament for $\mathrm{Sr}$ and in static mode using a double Re filament assembly for $\mathrm{Nd}$. The ${ }^{143} \mathrm{Nd} /{ }^{144} \mathrm{Nd}$ ratios were corrected for mass fractionation to ${ }^{146} \mathrm{Nd} /{ }^{144} \mathrm{Nd}=$ 0.7219 (Wasserburg et al. 1981), ${ }^{87} \mathrm{Sr} /{ }^{86} \mathrm{Sr}$ ratios assuming ${ }^{86} \mathrm{Sr} r{ }^{88} \mathrm{Sr}=0.1194$. External reproducibility is estimated from repeat analyses of the JNdil (Tanaka et al. 2000) $\left({ }^{143} \mathrm{Nd} /{ }^{144} \mathrm{Nd}=0.512107 \pm 28(2 \sigma, \mathrm{n}=10)\right)$ and NBS 987 $\left({ }^{87} \mathrm{Sr} /{ }^{86} \mathrm{Sr}=0.710239 \pm 26(2 \sigma, \mathrm{n}=17)\right)$. The decay constants applied to age-correct the isotopic ratios are from Steiger and Jäger (1977 - Sr) and Lugmair and Marti $(1978-\mathrm{Nd})$. The $\varepsilon_{\mathrm{Nd}}$ values were obtained using Bulk Earth parameters of Jacobsen and Wasserburg (1980), the single-stage Depleted Mantle Nd model ages $\left(T_{D M}^{N d}\right)$ were calculated after Liew and Hofmann (1988).

\section{Petrography and mineral composition}

\subsection{Gabbro-syenite group}

This group is characterized by the occurrence of medium- to coarse-grained rocks with variable contents of quartz, plagioclase and K-feldspar. Based on their modal compositions, the rocks can be classified as amphibole to amphibole-biotite monzogabbros, amphibole-biotite quartz diorites, biotite and amphibole-biotite syenites to quartz monzonites.

Subhedral hastingsite to ferrohornblende $(\mathrm{Si}=6.03-$ $6.60 \mathrm{apfu}, \mathrm{X}_{\mathrm{Mg}}=0.32-0.50$; Fig. 4a-b) with pargasite rim $\left(\mathrm{Si}=5.74-5.95 \mathrm{apfu}, \mathrm{X}_{\mathrm{Mg}}=0.59-0.71\right)$ is the dominant ferromagnesian mineral in the monzogabbro (Fig. 3a). Ferrohornblende to ferroedenite, sometimes with actinolite/magnesiohornblende symplectite in the core $(\mathrm{Si}$ $=6.65-7.90 \mathrm{apfu}, \mathrm{X}_{\mathrm{Mg}}=0.36-0.58$; Fig. 4a) is typical of majority of the rocks (Fig. 3b). Plagioclase in the monzogabbro occurs as lath-shaped to subhedral crystals

Fig. 3 Selected backscattered electron (BSE) and optical microscope images of the igneous rocks from the Sagsai Pluton and metamorphic rocks its contact aureole. a - Monzogabbro V027a consisting of subhedral plagioclase crystals with normal zoning and zoned crystals of amphibole (hastingsite core and pargasite-ferrohornblende rim) (BSE). b - Ferrohornblende with actinolite-magnesiohornblende symplectite in the core (BSE, sample V027a). c - Texture of the amphibole-biotite syenite (BSE, sample V027b). d - Muscovite-biotite granite containing subhedral plagioclase with cores affected by strong sericitization (XPL, sample V031). e - Garnet porphyroblast with abundant quartz and ilmenite inclusions (large ilmenite crystals in the upper part of the picture are partially replaced by rutile), from the stromatitic migmatite xenolith (BSE, sample P059c). f - Skeletal phenocryst of amphibole with abundant plagioclase and biotite inclusions in the porphyritic microdiorite (BSE, sample V023). g - Cordierite poikiloblast in the schist from the contact aureole of the Sagsai Pluton (XPL, sample D027). h-Chlorite and biotite porphyroblasts in the spotted schist (BSE, sample D026). 

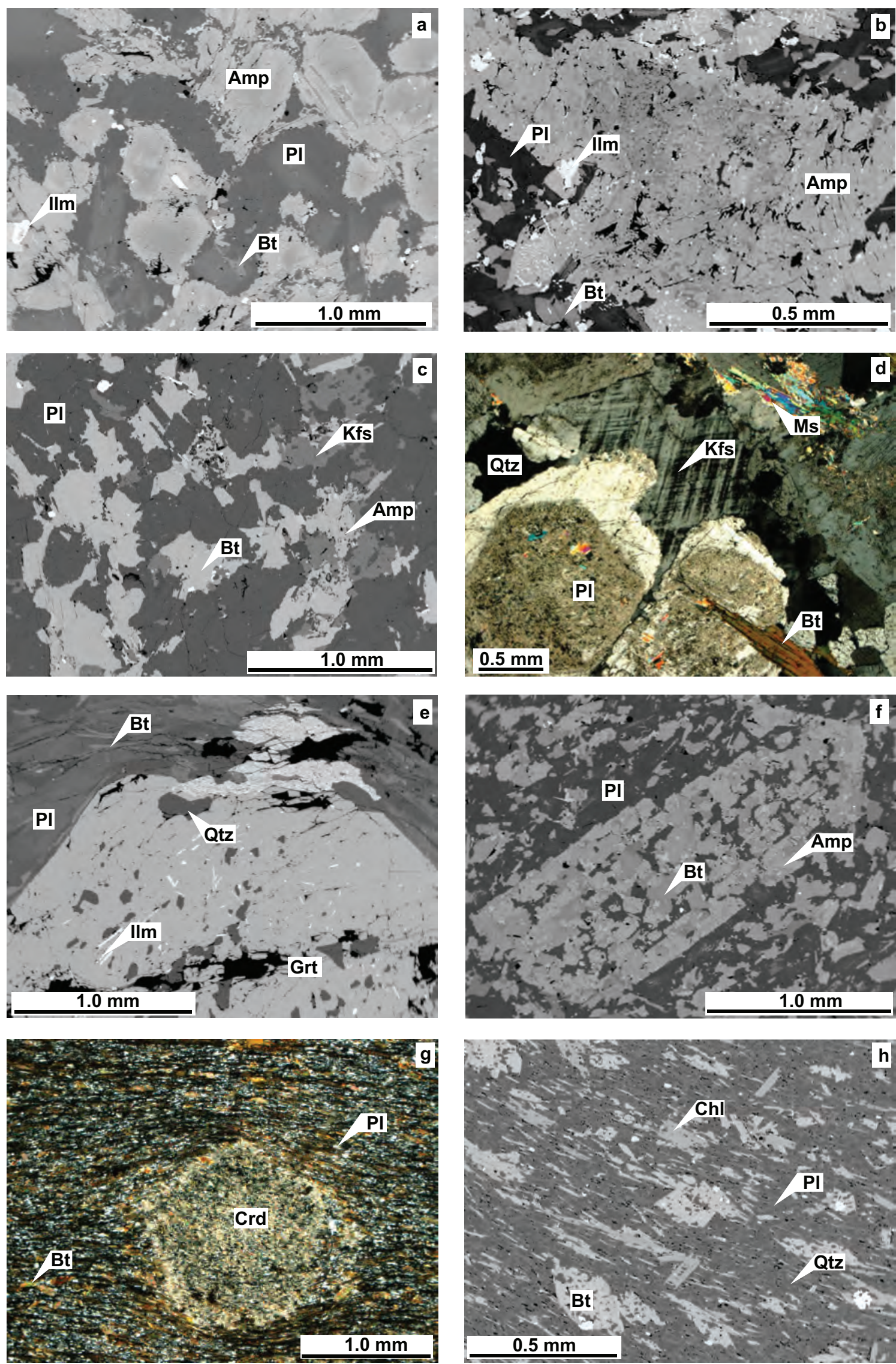

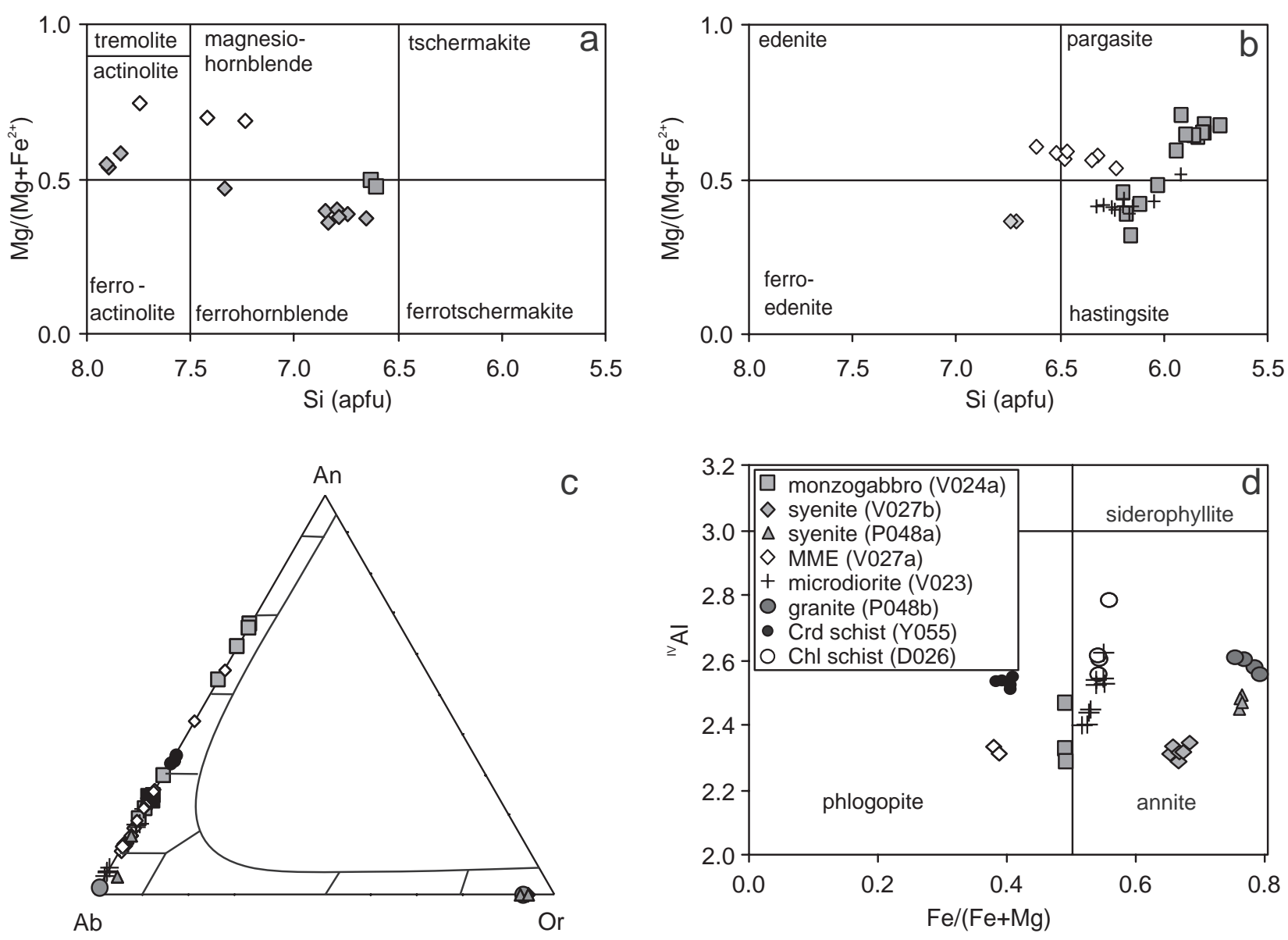

Fig. 4 Compositions of selected rock-forming minerals. $\mathbf{a}-\mathbf{b}-\mathrm{Mg} /\left(\mathrm{Mg}+\mathrm{Fe}^{2+}\right)$ vs. Si classification diagram for calcic amphiboles (Leake et al. 1997) with $\mathrm{Ca}_{\mathrm{B}} \geq 1.5,(\mathrm{Na}+\mathrm{K})_{\mathrm{A}}<0.5, \mathrm{Ca}_{\mathrm{A}}<0.5$ (a) and $\mathrm{Ca}_{\mathrm{B}} \geq 1.5,(\mathrm{Na}+\mathrm{K})_{\mathrm{A}} \geq 0.5$, Ti $<0.5$ (b). c - Ternary diagram Ab-An-Or for feldspar classification. $\mathbf{d}-{ }^{\mathrm{IV}} \mathrm{Al} \mathrm{vs} . \mathrm{Fe} /(\mathrm{Fe}+\mathrm{Mg})$ classification diagram of biotite.

with discontinuous zoning (labradorite core $\mathrm{Ab}_{32-46}$ and oligoclase rim $\mathrm{Ab}_{70-81}$; Fig. 4c). Plagioclase in the quartz monzonites and syenites (Fig. $3 \mathrm{c}$ ) forms usually subhedral crystals with oscillatory or normal zoning $\left(\mathrm{Ab}_{93-83}\right.$ $\left.\mathrm{Or}_{00-03}\right)$. Anhedral quartz and $\mathrm{K}$-feldspar $\left(\mathrm{Or}_{93-94} \mathrm{Ab}_{06-07}\right)$ with perthite exsolutions are locally common. Biotite flakes ( ${ }^{\mathrm{IV}} \mathrm{Al}=2.29-2.49$ apfu, $\mathrm{X}_{\mathrm{Fe}}=0.49-0.77$; Fig. 4d) are 0.1 to $0.3 \mathrm{~mm}$ in size and occur as individual crystals or aggregates associated with amphibole (Fig. 3c), titanite and apatite.

The MME have usually a fine-grained microgranular texture, sometimes with up to $2 \mathrm{~cm}$ long feldspar megacrysts. The contacts between enclaves and host rocks are mainly sharp, but in places diffuse. Compared with the host syenite and monzonite, MME generally contain the same mineral assemblage but with more amphibole and/or biotite, and less quartz and K-feldspar. Plagioclase in the MME of microgabbro composition occurs as euhedral to subhedral crystals with oscillatory or discontinuous zoning $\left(\mathrm{Ab}_{43-81}\right.$; Fig. 4c). Composition of anhedral crystal aggregates or subhedral amphibole crystals ranges from edenite through pargasite and magnesiohornblende to actinolite $\left(\mathrm{Si}=9.93-7.74\right.$ apfu, $\mathrm{X}_{\mathrm{Mg}}=0.53-0.74$; Fig. $4 \mathrm{a}-\mathrm{b})$. Subhedral biotite ( ${ }^{\mathrm{V}} \mathrm{Al}=2.31-2.33 \mathrm{apfu}$, $\mathrm{X}_{\mathrm{Fe}}=0.38-0.39$; Fig. $4 \mathrm{~d}$ ) is commonly associated with amphibole and hosts inclusions of euhedral to subhedral magnetite, ilmenite and needles of apatite.

Near the contact with roof pendants are observed rare xenoliths of biotite-rich, locally cordierite-bearing hornfelses (Fig. 2d). At the contact with gabbro bodies or mafic dykes are the fine-grained biotite-rich hornfelses affected by partial melting (Fig. 2f).

\subsection{Granite group}

Medium-grained muscovite-biotite granite is dominated by subhedral plagioclase $\left(\mathrm{Ab}_{87-98} ;\right.$ Fig. $\left.4 \mathrm{c}\right)$, anhedral perthitic K-feldspar $\left(\mathrm{Or}_{93-94} \mathrm{Ab}_{06-07}\right)$ and quartz. Sericitization is restricted to the cores of plagioclase (Fig. 3d). Muscovite (up to 2 vol. \%) and biotite (up to 6 vol. $\%$; ${ }^{\text {IV }} \mathrm{Al}=$ 2.60-2.61 apfu, $\mathrm{X}_{\mathrm{Fe}}=0.76-0.79$; Fig. 4d) both occur as 
long flakes. Granites contain angular migmatite enclaves a few centimetres to several meters in size.

\subsection{Stromatic migmatites}

Stromatitic migmatites are medium-grained with up to 1 $\mathrm{cm}$ thick leucosome layers. The biotite crystals are texturally and chemically similar to those in granite. Subhedral plagioclase (Fig. 3e) is weakly normally zoned $\left(\mathrm{Ab}_{81-98}\right.$ $\mathrm{Or}_{00-01}$ ) and subhedral to anhedral perthitic K-feldspar $\left(\mathrm{Or}_{93} \mathrm{Ab}_{7}\right)$. The orientation of sillimanite (fibrolite) is broadly parallel to the metamorphic foliation. Sillimanite needles are sometimes partially replaced by younger muscovite ( $\mathrm{Si}=6.82-6.83 \mathrm{apfu})$. Subhedral biotite ( ${ }^{\mathrm{IV}} \mathrm{Al}$ $=2.56-2.61 \mathrm{apfu}, \mathrm{X}_{\mathrm{Fe}}=0.76-0.79$; Fig. 4d) is slightly altered to chlorite. Rare are euhedral garnet porphyroblasts $\left(\mathrm{Alm}_{78-81} \mathrm{Adr}_{1-3} \mathrm{Grs}_{2-4} \operatorname{Prp}_{6-8} \mathrm{Sps}_{6-11}\right)$ up to $3 \mathrm{~mm}$ in size with abundant quartz and ilmenite inclusions (Fig. 3e).

\subsection{Dykes}

Several generations of felsic and mafic dykes appear within the Sagsai Pluton. Crosscutting relations suggest that plagioclase-rich fine-grained aplite $(\mathrm{Pl}+\mathrm{Qtz}+\mathrm{Kfs} \pm$ $\mathrm{Bt}$ ) can be considered as the oldest generation of dykes. Most of second-generation dykes have compositions of medium- to fine-grained microgabbro (Fig. 2e-f) and rare fine-grained microdiorite.

Porphyritic microdiorite represents the third generation of the dykes. Fine-grained, grey rocks contain amphibole and plagioclase phenocrysts up to $4 \mathrm{~cm}$ long. Plagioclase phenocrysts are chemically homogenous $\left(\mathrm{Ab}_{81-82}\right)$ with abundant inclusions of K-feldspar and biotite in the rim. Plagioclases in the matrix are normally zoned $\left(\mathrm{Ab}_{76-95}\right)$ with commonly corroded oligoclase cores. Amphibole forms small anhedral or skeletal crystals (Fig. 3f) with compositions ranging from hastingsite to pargasite $(\mathrm{Si}=$ $5.93-6.32$ apfu, $\left.\mathrm{X}_{\mathrm{Mg}}=0.39-0.52\right)$. Subhedral biotite ( ${ }^{\mathrm{IV}} \mathrm{Al}$ $\left.=2.45-2.61 \mathrm{apfu}, \mathrm{X}_{\mathrm{Fe}}=0.76-0.79\right)$ is slightly altered to chlorite.

\subsection{Rocks in the contact aureole of the Sagsai Pluton}

Two thermal metamorphic zones surround Sagsai Pluton: (I) cordierite schist occurring up to several hundred meters from the contact (cordierite zone) and (II) spotted schists containing muscovite-biotite spots (biotite zone) up to $1-2 \mathrm{~km}$ from the pluton.

Cordierite schist is a fine-grained, foliated rock dominated by quartz (40 vol. \%) and biotite (32\%), prevailing over cordierite (13\%), muscovite (11\%) and plagioclase $(4 \%)$. Anhedral quartz and plagioclase $\left(\mathrm{Ab}_{65-67}\right)$ are pres- ent as granular masses. Biotite $\left({ }^{\mathrm{IV}} \mathrm{Al}=2.51-2.55 \mathrm{apfu}\right.$, $\mathrm{X}_{\mathrm{Fe}}=0.38-0.41$; Fig. $4 \mathrm{~d}$ ) and muscovite occur as platy subhedral crystals up to $0.5 \mathrm{~mm}$ in length. Cordierite $\left(\mathrm{Al}=3.97-4.03 \mathrm{apfu}, \mathrm{X}_{\mathrm{Fe}}=0.26-0.27\right)$ forms small anhedral elongated crystals or poikiloblasts (Fig. $3 \mathrm{~g}$ ) with abundant inclusions of quartz and biotite up to $1 \mathrm{~mm}$ in length. It is often partially replaced by secondary minerals (mainly muscovite and chlorite).

Spotted schist is a fine-grained foliated rock dominated by quartz (35 vol. \%) and muscovite (30\%), prevailing over biotite (15\%), chlorite (12\%) as well as plagioclase $(8 \%)$. Anhedral quartz and normally zoned plagioclase $\left(\mathrm{Ab}_{74-78} ;\right.$ Fig. $\left.4 \mathrm{c}\right)$ are present as granular masses. Metamorphic foliation is defined mainly by the alignment of muscovite. Most biotite ( ${ }^{\mathrm{IV}} \mathrm{Al}=2.56-2.79 \mathrm{apfu}, \mathrm{X}_{\mathrm{Fe}}=$ $0.54-0.56$; Fig. $4 \mathrm{~d})$ and chlorite $\left(\mathrm{X}_{\mathrm{Fe}}=0.52\right)$ are aligned parallel to the foliation; however, some porphyroblasts have random orientations (Fig. 3h). Ilmenite, graphite, zircon and apatite are typical accessory phases in all metapelite samples from the contact aureole of the Sagsai Pluton.

\section{Zircon geochronology and in situ $\mathrm{Hf}$ isotopic composition}

\subsection{Zircon features}

Zircons are dominated by clear, euhedral and long prismatic crystals, ranging from 100 to $250 \mu \mathrm{m}$ in length. They generally display simple oscillatory zoning in CL images, implying igneous growth, and do not have inherited cores. Besides, a few zircons are subhedral and have thin young overgrowths (late or post-magmatic hydrothermal zircon).

\subsection{U-Pb zircon ages and Hf isotopic composition}

Sample Y047: isotopic analyses on thirteen grains yielded a simple population with weighted mean ${ }^{206} \mathrm{~Pb} /{ }^{238} \mathrm{U}$ age of $322 \pm 2 \mathrm{Ma}$ (Fig. 5a), which is interpreted as the crystallization age of the amphibole gabbro. A further analysis gave a relatively young age of $297 \mathrm{Ma}$, which could be a consequence of metamorphic disturbance. The c. $322 \mathrm{Ma}$ zircons have $\varepsilon_{H f}^{t}$ values between +7.4 and +11.5 , and $T_{D M}^{C}$ model ages range from 0.54 to $0.74 \mathrm{Ga}$.

Sample Y053: fifteen analyses of the oscillatory-zoned grains were conducted. Twelve of them gave a tight cluster of concordant points with a weighted mean ${ }^{206} \mathrm{~Pb} /{ }^{238} \mathrm{U}$ age of $307 \pm 2 \mathrm{Ma}$ (Fig. 5b), which is interpreted as the crystallization age of the biotite quartz monzonite. Three further analyses yielded older concordant ages ranging 

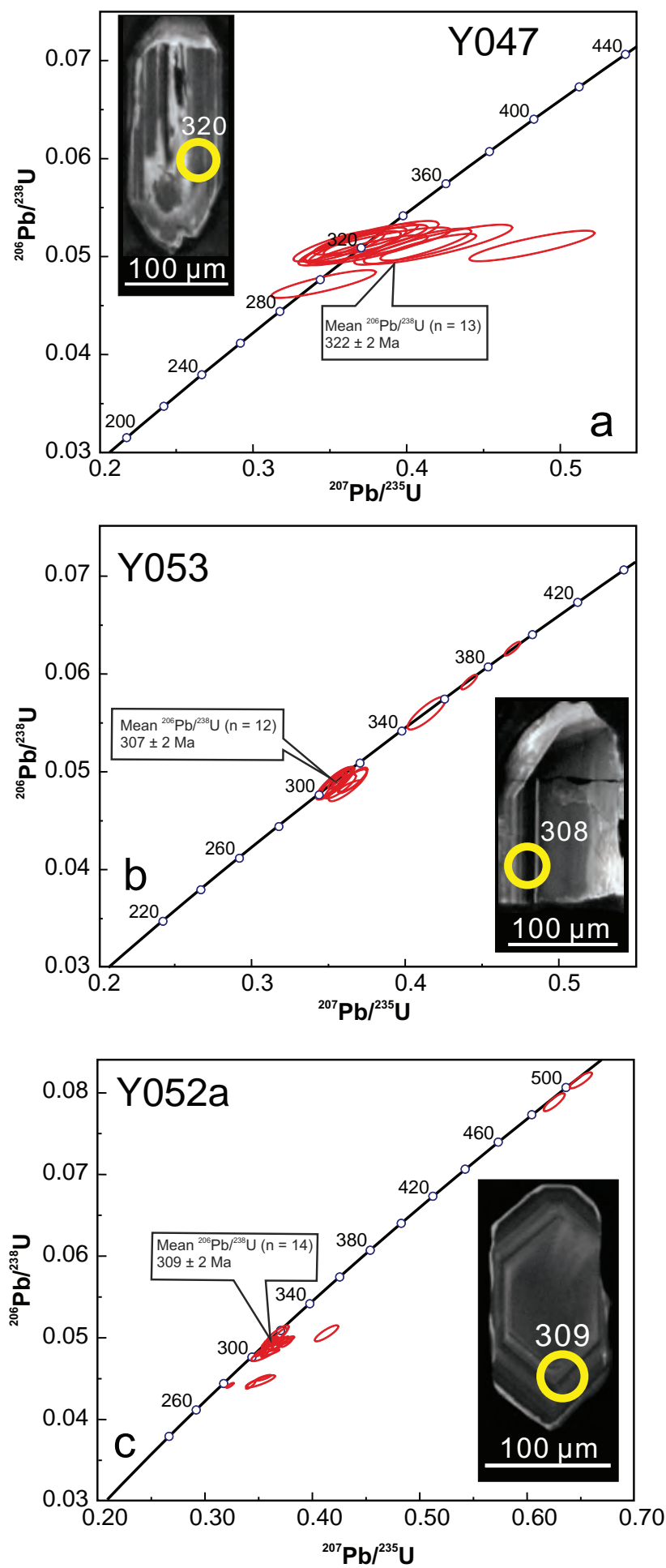

Fig. 5 Concordia diagrams for zircons from the Sagsai Pluton with representative cathodoluminescence images. a - Y047, amphibolebiotite monzogabbro; b - Y053, biotite quartz monzonite; $\mathbf{c}-$ Y052a, amphibole-biotite monzonite.

from 351 to $391 \mathrm{Ma}$, which are interpreted as xenocrysts possibly inherited from the host rocks. The c. $307 \mathrm{Ma}$ zircons have $\varepsilon_{H f}^{t}$ values between +3.7 and +8.4 with $T_{D M}^{C}$ model ages varying from 0.91 to $0.68 \mathrm{Ga}$. The xenocrysts have similar $\varepsilon_{H f}^{t}$ values of +4.1 to +9.6 , with calculated $T_{\mathrm{DM}}^{\mathrm{C}}$ model ages varying between $0.66 \mathrm{Ga}$ and $0.96 \mathrm{Ga}$.

Sample Y052a: twenty-five grains were selected for isotopic analysis. Fourteen of them form a cluster of concordant points with a weighted mean ${ }^{206} \mathrm{~Pb} /{ }^{238} \mathrm{U}$ age of $309 \pm 2 \mathrm{Ma}$ (Fig. 5c). This datum is taken to represent the crystallization age of the amphibole-biotite quartz monzonite. Analysis of two additional grains yielded concordant ages of 489 and $505 \mathrm{Ma}$, respectively, interpreted as xenocrysts from the country rocks. Besides, five analyses gave discordant ages, probably due to $\mathrm{Pb}$ loss, and were discarded. The $\varepsilon_{H f}^{t}$ values for the majority of the zircon population vary from +5.4 to +12.1 , with $T_{D M}^{C}$ model ages ranging from 0.50 to $0.83 \mathrm{Ga}$. The two older xenocrystic zircons yielded $\varepsilon_{H f}^{t}$ values of +12.5 and +13.8 , with corresponding $T_{D M}^{C}$ model ages of $0.63 \mathrm{Ga}$ and $0.58 \mathrm{Ga}$, respectively.

\section{Whole-rock geochemistry}

The Sagsai Pluton is characterized by a wide range of geochemical compositions, with the mafic rocks dominant. Granite group is chemically homogenous (Fig. 6a), while rocks of the gabbro-syenite group fall within the fields of quartz monzonite, syenite and foid monzogabbro to monzogabbro of the TAS (total alkalis versus silica) diagram (Middlemost 1994). Ultrabasic to intermediate rocks $\left(\mathrm{SiO}_{2}=41.4-62.9\right.$ wt. \%; Tab. 2a) are alkaline and the acidic rocks (granites and quartz monzonites, $\mathrm{SiO}_{2}=63.1-75.2$ wt. \%) subalkaline (Fig. 6a). Sodium prevails over potassium in nearly all samples $\left(\mathrm{K}_{2} \mathrm{O} / \mathrm{Na}_{2} \mathrm{O}=0.34-0.73\right.$ by weight, with P048a being just balanced). Based on Co and Th plot (Fig. 6b; Hastie et al. 2007) and $\mathrm{K}_{2} \mathrm{O}$ content (according to Peccerillo and Taylor 1976, not shown), all the rocks $\left(\mathrm{K}_{2} \mathrm{O}=2.7-5.1\right.$ wt. \%) except the intermediate syenites $\left(\mathrm{K}_{2} \mathrm{O}=1.3-3.5\right.$ wt. $\left.\%\right)$ are classified as medium-K calc-alkaline. Ferroan syenites and quartz monzonites (Fig. 6c; Frost et al. 2001) are subaluminous (A/CNK $<1.05)$ while the magnesian granites are only slightly peraluminous $(\mathrm{A} / \mathrm{CNK}=1.07-1.12)$ (Fig. 6d; Shand 1943). The felsic rocks (Fig. 6e) are characterized by relatively high $\mathrm{CaO} / \mathrm{Na}_{2} \mathrm{O}(0.31-0.86)$ and $\mathrm{Al}_{2} \mathrm{O}_{3} / \mathrm{TiO}_{2}$ (23-116) ratios.

Regarding the major and minor elements, the rocks of the gabbro-syenite group have higher $\mathrm{TiO}_{2}, \mathrm{FeO}_{\mathrm{t}}, \mathrm{MgO}$ and $\mathrm{CaO}$ than the granites (Fig. 7, Tab. 2a). Especially the (ultra-) basic rocks show the highest $\mathrm{TiO}_{2}, \mathrm{MgO}$, $\mathrm{CaO}, \mathrm{FeO}_{\mathrm{t}}, \mathrm{mg}$, and the lowest $\mathrm{Na}_{2} \mathrm{O}, \mathrm{K}_{2} \mathrm{O}, \mathrm{Rb}$ and $\mathrm{Zr}$ values. Microdiorite dyke displays chemical composition resembling gabbros but is characterised by slightly higher $\mathrm{Na}_{2} \mathrm{O}$ and $\mathrm{P}_{2} \mathrm{O}_{5}$ contents (Fig. 7). 
Tab. 2a Major-element (wt. \%) whole-rock chemical analyses from the Sagsai Pluton

\begin{tabular}{lrrrrrrrrrr}
\hline Sample & V021 & V031 & V025 & V024b & P048a & V027b & V023 & V024a & V027a & V022 \\
\hline $\mathrm{SiO}_{2}$ & 75.17 & 74.79 & 65.84 & 63.10 & 62.87 & 60.71 & 48.80 & 45.63 & 44.85 \\
$\mathrm{TiO}_{2}$ & 0.146 & 0.117 & 0.642 & 0.730 & 0.445 & 0.662 & 1.785 & 2.325 & 2.523 & 4.003 \\
$\mathrm{Al}_{2} \mathrm{O}_{3}$ & 14.42 & 13.62 & 15.83 & 16.98 & 18.14 & 18.59 & 17.83 & 17.98 & 15.55 & 17.48 \\
$\mathrm{Fe}_{2} \mathrm{O}_{3}$ & 1.59 & 1.32 & 4.47 & 5.33 & 4.53 & 5.48 & 10.88 & 12.19 & 12.26 & 13.40 \\
$\mathrm{MnO}$ & 0.035 & 0.037 & 0.072 & 0.077 & 0.127 & 0.094 & 0.171 & 0.185 & 0.174 & 0.161 \\
$\mathrm{MgO}$ & 0.40 & 0.31 & 0.89 & 1.35 & 0.70 & 1.05 & 3.62 & 4.73 & 7.16 & 7.01 \\
$\mathrm{CaO}$ & 1.46 & 1.48 & 2.48 & 4.01 & 1.90 & 2.99 & 5.41 & 9.19 & 9.93 & 9.90 \\
$\mathrm{Na}_{2} \mathrm{O}$ & 4.70 & 4.60 & 4.77 & 4.67 & 5.09 & 6.72 & 5.43 & 3.85 & 3.24 & 2.89 \\
$\mathrm{~K}_{2} \mathrm{O}$ & 2.27 & 2.26 & 3.49 & 2.40 & 5.08 & 2.65 & 2.46 & 1.32 & 1.74 & 1.53 \\
$\mathrm{P}_{2} \mathrm{O}_{5}$ & 0.05 & 0.02 & 0.23 & 0.29 & 0.18 & 0.28 & 0.78 & 0.43 & 0.45 & 0.25 \\
$\mathrm{LOI}$ & 0.62 & 0.46 & 0.61 & 0.63 & 0.31 & 0.49 & 1.88 & 0.93 & 1.09 & 1.33 \\
\hline $\mathrm{Sum}$ & 100.86 & 99.01 & 99.32 & 99.57 & 99.37 & 99.72 & 99.05 & 98.76 & 98.97 & 99.37 \\
\hline $\mathrm{mg} \#$ & 33.26 & 31.75 & 28.29 & 33.41 & 23.44 & 27.51 & 39.73 & 43.46 & 53.64 & 50.89 \\
$\mathrm{~A} / \mathrm{CNK}$ & 1.12 & 1.07 & 0.98 & 0.97 & 1.05 & 0.96 & 0.83 & 0.73 & 0.62 & 0.72 \\
$\mathrm{~K}_{2} \mathrm{O} / \mathrm{Na}_{2} \mathrm{O}$ & 0.48 & 0.49 & 0.73 & 0.51 & 1.00 & 0.39 & 0.45 & 0.34 & 0.54 & 0.53 \\
\hline
\end{tabular}
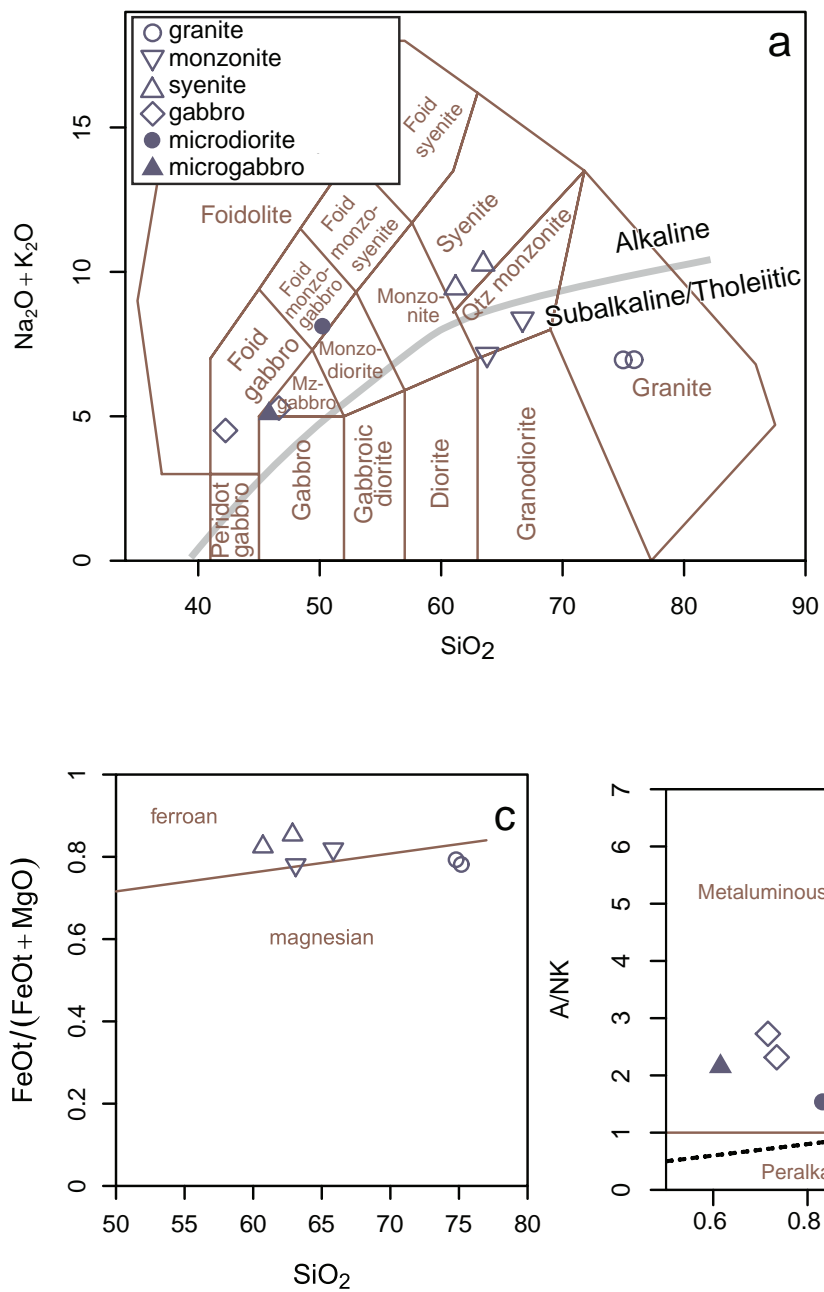

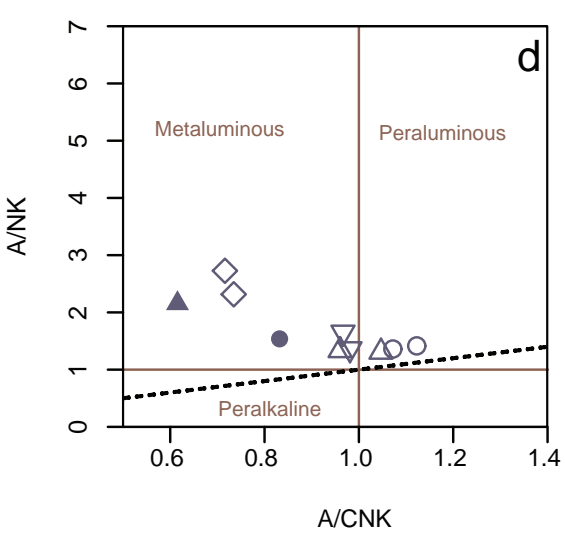

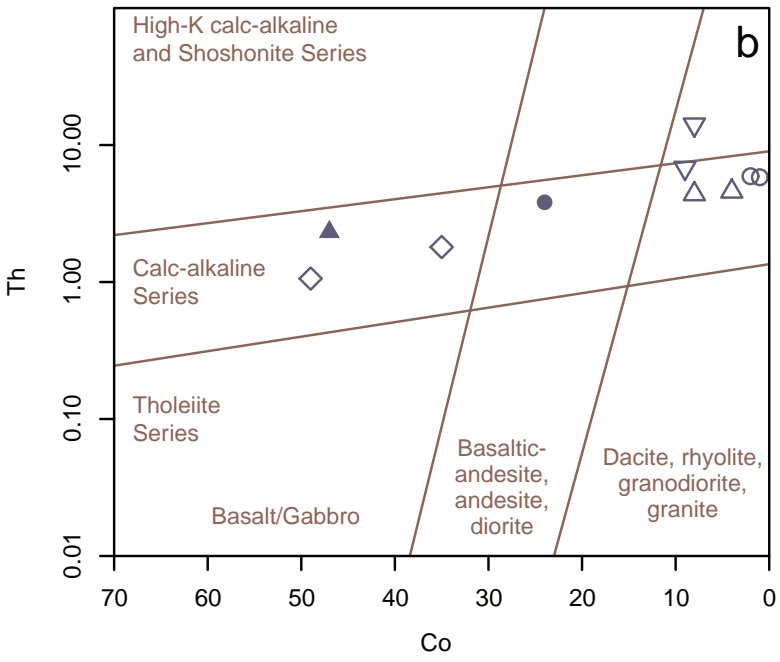

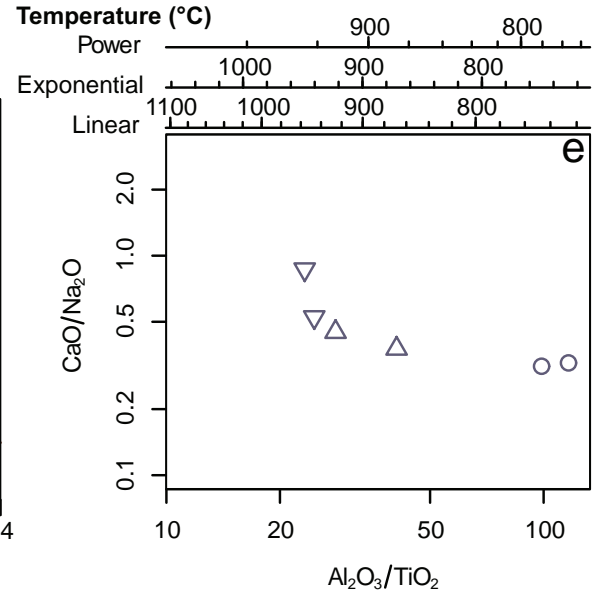

Fig. 6 Chemical classification of rocks from the Sagsai Pluton. a - Total alkali vs. silica (TAS) diagram (Middlemost 1994; thick solid line shows boundary between alkaline and subalkaline rocks according to Irvine and Baragar 1971). b - Th vs. Co diagram (Hastie et al. 2007). c - FeO/(FeO, $+\mathrm{MgO}$ ) vs. $\mathrm{SiO}_{2}$ diagram (Frost et al. 2001). d-A/NK vs. A/CNK diagram (Shand 1943). c $-\mathrm{CaO} / \mathrm{Na}_{2} \mathrm{O}$ vs. $\mathrm{Al}_{2} \mathrm{O}_{3} / \mathrm{TiO}_{2}$ diagram (Sylvester 1998 ) with granitic melt temperature calculated for melt derived from psammitic sources after Jung and Pfänder (2007). 
Tab. 2b Trace-element (ppm) whole-rock chemical analyses from the Sagsai Pluton

\begin{tabular}{|c|c|c|c|c|c|c|c|c|c|c|}
\hline Sample & V021 & V031 & V025 & $\mathrm{V} 024 \mathrm{~b}$ & P048a & $\mathrm{V} 027 \mathrm{~b}$ & V023 & $\mathrm{V} 024 \mathrm{a}$ & $\mathrm{V} 027 \mathrm{a}$ & V022 \\
\hline $\mathrm{Sc}$ & 2 & 2 & 3 & 5 & 2 & 2 & 9 & 24 & 24 & 32 \\
\hline $\mathrm{Be}$ & 1 & 1 & 3 & 2 & 2 & 2 & 3 & 1 & 2 & $<1$ \\
\hline $\mathrm{V}$ & 15 & 12 & 40 & 46 & 24 & 30 & 66 & 268 & 259 & 435 \\
\hline $\mathrm{Cr}$ & $<20$ & $<20$ & $<20$ & $<20$ & $<20$ & $<20$ & 90 & $<20$ & 220 & $<20$ \\
\hline $\mathrm{Co}$ & 2 & 1 & 8 & 9 & 4 & 8 & 24 & 35 & 47 & 49 \\
\hline $\mathrm{Ni}$ & $<20$ & $<20$ & $<20$ & $<20$ & $<20$ & $<20$ & 50 & $<20$ & 110 & 20 \\
\hline $\mathrm{Cu}$ & $<10$ & $<10$ & 10 & 50 & $<10$ & 20 & 30 & 50 & 60 & 40 \\
\hline $\mathrm{Zn}$ & 40 & 40 & 50 & 50 & 60 & 70 & 80 & 80 & 90 & 80 \\
\hline $\mathrm{Ga}$ & 20 & 19 & 20 & 20 & 21 & 22 & 18 & 21 & 20 & 19 \\
\hline $\mathrm{Ge}$ & 1.3 & 0.9 & 1.6 & 1.0 & 1.4 & 1.5 & 1.5 & 1.6 & 1.8 & 1.7 \\
\hline As & $<5$ & $<5$ & $<5$ & $<5$ & $<5$ & $<5$ & $<5$ & $<5$ & $<5$ & $<5$ \\
\hline $\mathrm{Rb}$ & 45 & 43 & 72 & 45 & 76 & 42 & 26 & 14 & 23 & 14 \\
\hline $\mathrm{Sr}$ & 233 & 232 & 446 & 485 & 296 & 1119 & 1813 & 569 & 601 & 729 \\
\hline Y & 5.3 & 5.5 & 15.7 & 13.3 & 14.6 & 11.5 & 24.7 & 25.8 & 20.4 & 25.2 \\
\hline $\mathrm{Zr}$ & 73 & 71 & 216 & 311 & 438 & 455 & 296 & 180 & 182 & 158 \\
\hline $\mathrm{Nb}$ & 12.6 & 12.5 & 43.7 & 24.6 & 32.8 & 29.4 & 67.7 & 29.9 & 33.6 & 32.3 \\
\hline Mo & $<2$ & $<2$ & $<2$ & $<2$ & $<2$ & $<2$ & $<2$ & $<2$ & 2 & $<2$ \\
\hline $\mathrm{Ag}$ & $<0.5$ & $<0.5$ & $<0.5$ & 1.1 & 2.8 & 2.2 & 1.2 & $<0.5$ & $<0.5$ & $<0.5$ \\
\hline In & $<0.1$ & $<0.1$ & $<0.1$ & $<0.1$ & $<0.1$ & $<0.1$ & $<0.1$ & $<0.1$ & $<0.1$ & $<0.1$ \\
\hline $\mathrm{Sn}$ & $<1$ & $<1$ & 3 & $<1$ & 1 & 2 & 2 & 2 & 2 & 1 \\
\hline $\mathrm{Sb}$ & $<0.2$ & $<0.2$ & 1.2 & $<0.2$ & $<0.2$ & $<0.2$ & $<0.2$ & $<0.2$ & $<0.2$ & $<0.2$ \\
\hline $\mathrm{Cs}$ & 0.4 & 0.4 & 1.3 & 0.7 & 1.4 & 0.9 & 0.3 & 0.2 & 1.3 & 0.2 \\
\hline $\mathrm{Ba}$ & 498 & 545 & 664 & 427 & 646 & 734 & 683 & 193 & 225 & 242 \\
\hline $\mathrm{La}$ & 23.2 & 21.0 & 42.8 & 30.7 & 21.2 & 33.5 & 48.5 & 22.4 & 24.4 & 14.3 \\
\hline $\mathrm{Ce}$ & 39.1 & 35.8 & 74.4 & 52.0 & 35.5 & 56.6 & 93.4 & 46.3 & 50.8 & 32.4 \\
\hline $\operatorname{Pr}$ & 3.78 & 3.60 & 7.46 & 5.34 & 3.66 & 5.63 & 10.40 & 5.68 & 6.04 & 4.31 \\
\hline $\mathrm{Nd}$ & 13.0 & 12.1 & 25.9 & 19.9 & 13.1 & 20.2 & 40.6 & 24.0 & 25.5 & 20.1 \\
\hline $\mathrm{Sm}$ & 2.19 & 2.08 & 4.79 & 3.94 & 2.85 & 3.72 & 8.21 & 5.92 & 6.00 & 5.62 \\
\hline $\mathrm{Eu}$ & 0.489 & 0.486 & 1.46 & 1.15 & 1.04 & 1.66 & 2.87 & 1.92 & 1.93 & 1.97 \\
\hline Gd & 1.31 & 1.48 & 3.84 & 3.11 & 2.71 & 2.80 & 6.47 & 5.52 & 5.49 & 5.40 \\
\hline $\mathrm{Tb}$ & 0.20 & 0.19 & 0.55 & 0.46 & 0.45 & 0.41 & 0.96 & 0.87 & 0.84 & 0.91 \\
\hline Dy & 0.98 & 0.98 & 2.96 & 2.60 & 2.70 & 2.25 & 5.17 & 5.23 & 4.50 & 5.26 \\
\hline Ho & 0.17 & 0.18 & 0.57 & 0.54 & 0.54 & 0.42 & 0.97 & 1.01 & 0.81 & 0.99 \\
\hline $\mathrm{Er}$ & 0.53 & 0.46 & 1.65 & 1.58 & 1.52 & 1.21 & 2.70 & 2.86 & 2.17 & 2.71 \\
\hline $\mathrm{Tm}$ & 0.077 & 0.075 & 0.234 & 0.239 & 0.229 & 0.170 & 0.369 & 0.399 & 0.290 & 0.351 \\
\hline $\mathrm{Yb}$ & 0.51 & 0.50 & 1.65 & 1.69 & 1.50 & 1.29 & 2.30 & 2.50 & 1.82 & 2.26 \\
\hline $\mathrm{Lu}$ & 0.086 & 0.084 & 0.279 & 0.278 & 0.248 & 0.210 & 0.393 & 0.418 & 0.273 & 0.364 \\
\hline $\mathrm{Hf}$ & 2.4 & 2.0 & 5.0 & 6.6 & 8.5 & 7.5 & 6.0 & 4.0 & 4.0 & 3.5 \\
\hline $\mathrm{Ta}$ & 1.39 & 1.84 & 3.85 & 1.55 & 1.72 & 1.82 & 4.18 & 2.05 & 2.34 & 1.99 \\
\hline W & $<0.5$ & $<0.5$ & $<0.5$ & $<0.5$ & $<0.5$ & $<0.5$ & $<0.5$ & $<0.5$ & $<0.5$ & $<0.5$ \\
\hline $\mathrm{Tl}$ & 0.07 & $<0.05$ & 0.13 & 0.09 & 0.19 & $<0.05$ & $<0.05$ & $<0.05$ & $<0.05$ & $<0.05$ \\
\hline $\mathrm{Pb}$ & 9 & 8 & 8 & 5 & 11 & 7 & $<5$ & $<5$ & $<5$ & $<5$ \\
\hline $\mathrm{Bi}$ & $<0.1$ & $<0.1$ & $<0.1$ & $<0.1$ & $<0.1$ & $<0.1$ & $<0.1$ & $<0.1$ & $<0.1$ & $<0.1$ \\
\hline Th & 5.92 & 5.82 & 14.1 & 6.81 & 4.58 & 4.38 & 3.82 & 1.80 & 2.32 & 1.06 \\
\hline $\mathrm{U}$ & 1.02 & 0.93 & 2.52 & 1.95 & 2.48 & 1.76 & 1.29 & 0.64 & 0.85 & 0.43 \\
\hline $\mathrm{Eu} / \mathrm{Eu}^{*}$ & 0.88 & 0.85 & 1.04 & 1.00 & 1.14 & 1.57 & 1.20 & 1.03 & 1.03 & 1.09 \\
\hline $\mathrm{La}_{\mathrm{N}} / \mathrm{Yb}_{\mathrm{N}}$ & 30.67 & 28.32 & 17.49 & 12.25 & 9.53 & 17.51 & 14.22 & 6.04 & 9.04 & 4.27 \\
\hline Sum REE & 85.62 & 79.02 & 168.54 & 123.53 & 87.25 & 130.07 & 223.31 & 125.03 & 130.86 & 96.95 \\
\hline
\end{tabular}

As seen in Fig. 8a, the relatively immobile trace elements $\mathrm{Th}, \mathrm{U}, \mathrm{Nb}$, and the LREE (Light Rare Earth Elements) in the basic and ultrabasic rocks are strongly enriched compared to N-MORB (Sun and McDonough 1989); normalized contents of $Y$ and the HREE (Heavy Rare Earth Elements) are close to unity. Noteworthy is the fact that negative $\mathrm{Nb}$ and $\mathrm{Ti}$ anomalies are absent, as is largely the case for the $\mathrm{Pb}$ spike typical of the acid-intermediate rocks. In particular, the multielement patterns of microdiorites and microgabbros resemble that for the average Ocean-Island Basalt (OIB) (Sun and McDonough 1989, Fig. 8a). In accord with their observed modal lay- 

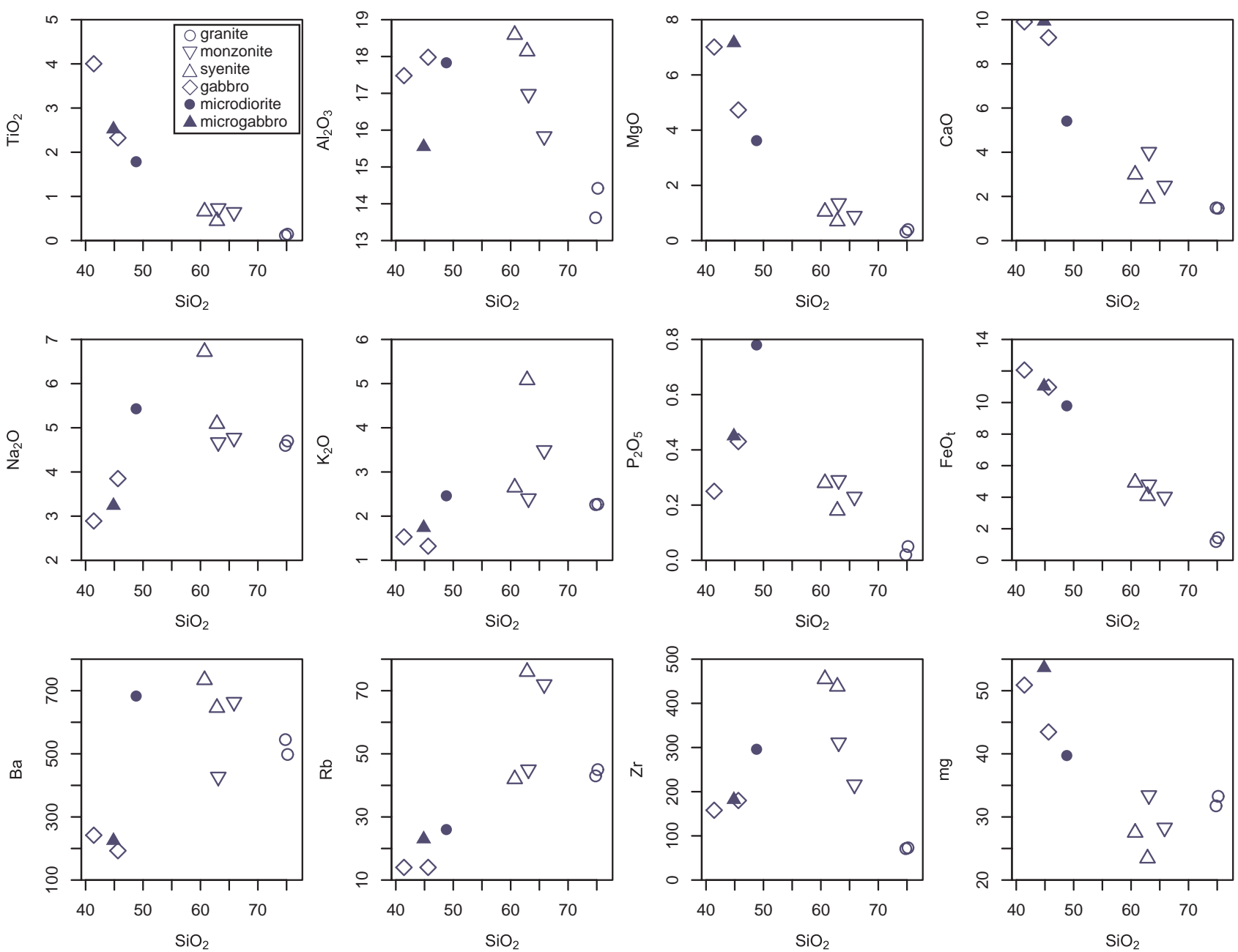

Fig. 7 Multiple plots of $\mathrm{SiO}_{2}$ vs. selected major-element oxides and trace elements for igneous rocks from the Sagsai Pluton.

ering, the gabbros seem to be partially affected by the crystal accumulation.

The N-MORB normalized patterns for acid to intermediate rocks (Fig. 8b) show considerable degree of enrichment in incompatible elements. All patterns are characterized by the presence of $\mathrm{K}$ and $\mathrm{Pb}$ spikes and $\mathrm{Nb}, \mathrm{P}$ and Ti troughs. The syenites and quartz monzonites (Fig. 8b) are enriched in U, Nb, Sr, P, Zr, Ti and HREE relative to the granite patterns, mostly resembling the average continental crustal abundances determined by Taylor and McLennan (1995) (Fig. 8b). The Granite group is characterized by strong depletion in P and HREE if compared with the average NMORB.

The REE data are plotted in chondrite-normalised (Boynton 1984) spiderplot (Fig. 9). The granites show strongly HREE-depleted REE patterns $\left(\mathrm{La}_{\mathrm{N}} / \mathrm{Yb}_{\mathrm{N}}=\right.$ 28.3-30.7) with slightly negative Eu anomalies (Eu/Eu* $=0.8-0.9$ ). In contrast, the rocks of the gabbro-syenite group display relatively weak LREE/HREE enrichments $\left(\mathrm{La}_{\mathrm{N}} / \mathrm{Yb}_{\mathrm{N}}=4.3-17.5\right)$, higher HREE contents and no or positive $\mathrm{Eu}$ anomalies $\left(\mathrm{Eu} / \mathrm{Eu}^{*}=1.0-1.6\right)$.

\section{7. $\mathrm{Sr}-\mathrm{Nd}$ isotope geochemistry}

Whole-rock $\mathrm{Nd}$ and, degree of alteration permitting, $\mathrm{Sr}$ isotopic data were obtained in order to constrain the geochemical character, source and likely petrogenesis of the Sagsai plutonic rocks. The new data, age-corrected to $310 \mathrm{Ma}$, are summarized in Tab. 4. The age preferred for the back-calculation of isotopic ratios is based on the two dated samples (Y047, Y052), which come from the same rock types as samples V024 and V027, respectively (Tab. 4, see also Tab. 1).

The (ultra-) basic rock types have unradiogenic $\mathrm{Sr}$ and strongly radiogenic $\mathrm{Nd}$ isotopic compositions corresponding to the OIB-source at $310 \mathrm{Ma}\left({ }^{87} \mathrm{Sr} /{ }^{86} \mathrm{Sr}_{310} \sim 0.7026\right.$, $\left.\varepsilon_{N d}^{310} \sim+8\right)$ (Fig. 10). The depleted-mantle Nd model ages $T_{D M}^{N d}$ (calculated using the single-stage model of Liew and Hofmann 1988) are rather uniform at $\sim 0.39-0.44$ $\mathrm{Ga}$. However, a notable exception among the basic rocks represents the amphibole gabbro sample V022 with less radiogenic $\mathrm{Nd}\left({ }^{87} \mathrm{Sr} /{ }^{86} \mathrm{Sr}_{310}=0.7025, \varepsilon_{N d}^{310}=+6.4 ; T_{D M}^{N d}=\right.$ $0.73 \mathrm{Ga})$. 
Tab. 3 Hf-in-zircon analytical data for dated zircons

\begin{tabular}{|c|c|c|c|c|c|c|c|c|c|c|c|}
\hline Analysis & ${ }^{176} \mathrm{Hf} /{ }^{177} \mathrm{Hf}$ & $\pm(2 \sigma)$ & ${ }^{176} \mathrm{Lu} /{ }^{177} \mathrm{Hf}$ & $\pm(2 \sigma)$ & ${ }^{176} \mathrm{Yb} /{ }^{177} \mathrm{Hf}$ & $\pm(2 \sigma)$ & Age (Ma) & $\left.{ }^{(176} \mathrm{Hf} /{ }^{177} \mathrm{Hf}\right)$ & $\varepsilon_{H f}^{t}$ & $T_{D M}^{C}$ & $\pm(2 \sigma)$ \\
\hline Y047-1 & 0.282885 & 0.000024 & 0.005212 & 0.000021 & 0.173174 & 0.001353 & 325 & 0.282853 & 10.0 & 0.61 & 0.08 \\
\hline Y047-2 & 0.282885 & 0.000019 & 0.002379 & 0.000032 & 0.085365 & 0.001043 & 321 & 0.282871 & 10.5 & 0.58 & 0.06 \\
\hline Y047-4 & 0.282819 & 0.000021 & 0.003767 & 0.000041 & 0.136850 & 0.001052 & 320 & 0.282796 & 7.9 & 0.72 & 0.06 \\
\hline Y047-3 & 0.282845 & 0.000025 & 0.005397 & 0.000071 & 0.189970 & 0.003318 & 321 & 0.282812 & 8.5 & 0.69 & 0.08 \\
\hline Y047-5 & 0.282884 & 0.000023 & 0.003132 & 0.000045 & 0.123269 & 0.001681 & 322 & 0.282865 & 10.4 & 0.59 & 0.07 \\
\hline Y047-6 & 0.282881 & 0.000022 & 0.002714 & 0.000036 & 0.097965 & 0.001726 & 325 & 0.282864 & 10.4 & 0.59 & 0.06 \\
\hline Y047-7 & 0.282846 & 0.000021 & 0.003827 & 0.000040 & 0.133585 & 0.000846 & 297 & 0.282824 & 8.4 & 0.67 & 0.06 \\
\hline Y047-8 & 0.282863 & 0.000023 & 0.002501 & 0.000084 & 0.097642 & 0.003067 & 319 & 0.282848 & 9.7 & 0.63 & 0.07 \\
\hline Y047-9 & 0.282806 & 0.000022 & 0.003711 & 0.000227 & 0.129211 & 0.008084 & 320 & 0.282783 & 7.4 & 0.74 & 0.07 \\
\hline Y047-11 & 0.282829 & 0.000020 & 0.003734 & 0.000049 & 0.134053 & 0.001855 & 322 & 0.282806 & 8.3 & 0.70 & 0.06 \\
\hline Y047-12 & 0.282890 & 0.000020 & 0.002701 & 0.000089 & 0.093524 & 0.002889 & 320 & 0.282874 & 10.6 & 0.58 & 0.06 \\
\hline Y047-14 & 0.282844 & 0.000021 & 0.003812 & 0.000120 & 0.134636 & 0.004011 & 321 & 0.282821 & 8.8 & 0.67 & 0.06 \\
\hline Y047-13 & 0.282864 & 0.000023 & 0.003324 & 0.000044 & 0.125932 & 0.001340 & 321 & 0.282844 & 9.6 & 0.63 & 0.07 \\
\hline Y047-15 & 0.282905 & 0.000020 & 0.001592 & 0.000047 & 0.059398 & 0.002145 & 324 & 0.282895 & 11.5 & 0.54 & 0.06 \\
\hline Y052a-2 & 0.282863 & 0.000028 & 0.001534 & 0.000030 & 0.038062 & 0.000762 & 317 & 0.282854 & 9.8 & 0.62 & 0.08 \\
\hline Y052a-4 & 0.282814 & 0.000030 & 0.002150 & 0.000034 & 0.054660 & 0.000866 & 318 & 0.282801 & 8.0 & 0.71 & 0.09 \\
\hline Y052a-6 & 0.282837 & 0.000028 & 0.000678 & 0.000002 & 0.016469 & 0.000039 & 279 & 0.282834 & 8.3 & 0.66 & 0.08 \\
\hline Y052a-8 & 0.282838 & 0.000033 & 0.001242 & 0.000015 & 0.032176 & 0.000379 & 279 & 0.282831 & 8.2 & 0.66 & 0.09 \\
\hline Y052a-9 & 0.282816 & 0.000025 & 0.000607 & 0.000003 & 0.014886 & 0.000081 & 312 & 0.282812 & 8.3 & 0.69 & 0.07 \\
\hline Y052a-10 & 0.282868 & 0.000035 & 0.002203 & 0.000022 & 0.056119 & 0.000607 & 505 & 0.282847 & 13.8 & 0.58 & 0.10 \\
\hline Y052a-11 & 0.282809 & 0.000028 & 0.000653 & 0.000003 & 0.015307 & 0.000075 & 303 & 0.282805 & 7.8 & 0.70 & 0.08 \\
\hline Y052a-12 & 0.282831 & 0.000031 & 0.002292 & 0.000028 & 0.058644 & 0.000776 & 311 & 0.282818 & 8.4 & 0.68 & 0.09 \\
\hline Y052a-13 & 0.282915 & 0.000029 & 0.001390 & 0.000009 & 0.033828 & 0.000233 & 304 & 0.282907 & 11.5 & 0.52 & 0.08 \\
\hline Y052a-14 & 0.282826 & 0.000026 & 0.000584 & 0.000008 & 0.014234 & 0.000211 & 489 & 0.282821 & 12.5 & 0.63 & 0.07 \\
\hline Y052a-15 & 0.282876 & 0.000032 & 0.002606 & 0.000064 & 0.069740 & 0.001851 & 313 & 0.282861 & 10.0 & 0.60 & 0.10 \\
\hline Y052a-16 & 0.282781 & 0.000038 & 0.001127 & 0.000007 & 0.028322 & 0.000186 & 303 & 0.282774 & 6.7 & 0.76 & 0.11 \\
\hline Y052a-17 & 0.282833 & 0.000030 & 0.002234 & 0.000025 & 0.056245 & 0.000662 & 311 & 0.282820 & 8.5 & 0.68 & 0.09 \\
\hline Y052a-18 & 0.282814 & 0.000040 & 0.002368 & 0.000015 & 0.057650 & 0.000399 & 303 & 0.282801 & 7.7 & 0.71 & 0.12 \\
\hline Y052a-19 & 0.282871 & 0.000025 & 0.001867 & 0.000027 & 0.047161 & 0.000695 & 284 & 0.282861 & 9.4 & 0.61 & 0.07 \\
\hline Y052a-20 & 0.282834 & 0.000027 & 0.001562 & 0.000022 & 0.037736 & 0.000645 & 312 & 0.282824 & 8.7 & 0.67 & 0.08 \\
\hline Y052a-21 & 0.282931 & 0.000036 & 0.001607 & 0.000028 & 0.040259 & 0.000725 & 309 & 0.282922 & 12.1 & 0.50 & 0.10 \\
\hline Y052a-22 & 0.282846 & 0.000032 & 0.001643 & 0.000044 & 0.041838 & 0.001213 & 311 & 0.282836 & 9.1 & 0.65 & 0.09 \\
\hline Y052a-27 & 0.282737 & 0.000057 & 0.001124 & 0.000011 & 0.028583 & 0.000320 & 311 & 0.282731 & 5.4 & 0.83 & 0.16 \\
\hline Y053-1 & 0.282717 & 0.000026 & 0.005084 & 0.000144 & 0.171318 & 0.005547 & 309 & 0.282688 & 3.8 & 0.91 & 0.08 \\
\hline Y053-2 & 0.282811 & 0.000023 & 0.001604 & 0.000031 & 0.051952 & 0.001284 & 306 & 0.282802 & 7.8 & 0.71 & 0.06 \\
\hline Y053-3 & 0.282844 & 0.000026 & 0.004274 & 0.000017 & 0.147647 & 0.001129 & 305 & 0.282819 & 8.4 & 0.68 & 0.08 \\
\hline Y053-4 & 0.282822 & 0.000024 & 0.002979 & 0.000123 & 0.102250 & 0.004526 & 307 & 0.282805 & 7.9 & 0.70 & 0.07 \\
\hline Y053-5 & 0.282814 & 0.000022 & 0.002369 & 0.000035 & 0.075997 & 0.001495 & 306 & 0.282801 & 7.7 & 0.71 & 0.06 \\
\hline Y053-7 & 0.282823 & 0.000021 & 0.001301 & 0.000016 & 0.039666 & 0.000545 & 371 & 0.282814 & 9.6 & 0.67 & 0.06 \\
\hline Y053-8 & 0.282809 & 0.000022 & 0.002969 & 0.000061 & 0.089324 & 0.002271 & 306 & 0.282792 & 7.4 & 0.73 & 0.07 \\
\hline Y053-9 & 0.282771 & 0.000025 & 0.005353 & 0.000164 & 0.182786 & 0.005421 & 308 & 0.282740 & 5.6 & 0.82 & 0.08 \\
\hline Y053-10 & 0.282834 & 0.000025 & 0.001341 & 0.000009 & 0.036570 & 0.000304 & 351 & 0.282825 & 9.6 & 0.66 & 0.07 \\
\hline Y053-11 & 0.282802 & 0.000025 & 0.005350 & 0.000060 & 0.186701 & 0.002195 & 306 & 0.282772 & 6.7 & 0.76 & 0.08 \\
\hline Y053-12 & 0.282802 & 0.000023 & 0.004890 & 0.000100 & 0.161144 & 0.003491 & 309 & 0.282773 & 6.8 & 0.76 & 0.07 \\
\hline Y053-13 & 0.282723 & 0.000026 & 0.006391 & 0.000093 & 0.217064 & 0.002684 & 305 & 0.282687 & 3.7 & 0.91 & 0.09 \\
\hline Y053-14 & 0.282756 & 0.000028 & 0.005243 & 0.000153 & 0.178777 & 0.005992 & 308 & 0.282726 & 5.1 & 0.84 & 0.09 \\
\hline Y053-15 & 0.282781 & 0.000022 & 0.003517 & 0.000007 & 0.122159 & 0.000343 & 310 & 0.282761 & 6.4 & 0.78 & 0.07 \\
\hline Y053-16 & 0.282662 & 0.000028 & 0.002419 & 0.000087 & 0.079962 & 0.003544 & 391 & 0.282644 & 4.1 & 0.96 & 0.08 \\
\hline
\end{tabular}

The coarse-grained granite V021 is significantly more evolved but its composition still falls into the depleted quadrant of the ${ }^{87} \mathrm{Sr} /{ }^{86} \mathrm{Sr}_{310}$ vs. $\varepsilon_{N d}^{310}$ plot $\left({ }^{87} \mathrm{Sr}^{/ 86} \mathrm{Sr}_{310}=0.7038\right.$, $\left.\varepsilon_{N d}^{310} \sim+5.8, T_{D M}^{N d}=0.53 \mathrm{Ga}\right)$. The sample $\mathrm{V} 024 \mathrm{~b}$ shows $\mathrm{Sr}-$ $\mathrm{Nd}$ isotopic composition intermediate between these two extremes $\left({ }^{87} \mathrm{Sr}^{86} \mathrm{Sr}_{310}=0.7030, \varepsilon_{N d}^{310} \sim+6.8, T_{D M}^{N d}=0.49 \mathrm{Ga}\right)$.

\section{P-T conditions}

Late Paleozoic alkaline massifs in southern Mongolia are often associated with volcanic rocks (e.g. Kovalenko et al. 2006; Buriánek et al. 2012). This suggests an intrusion at relative shallow crustal levels; however, its exact mecha- 


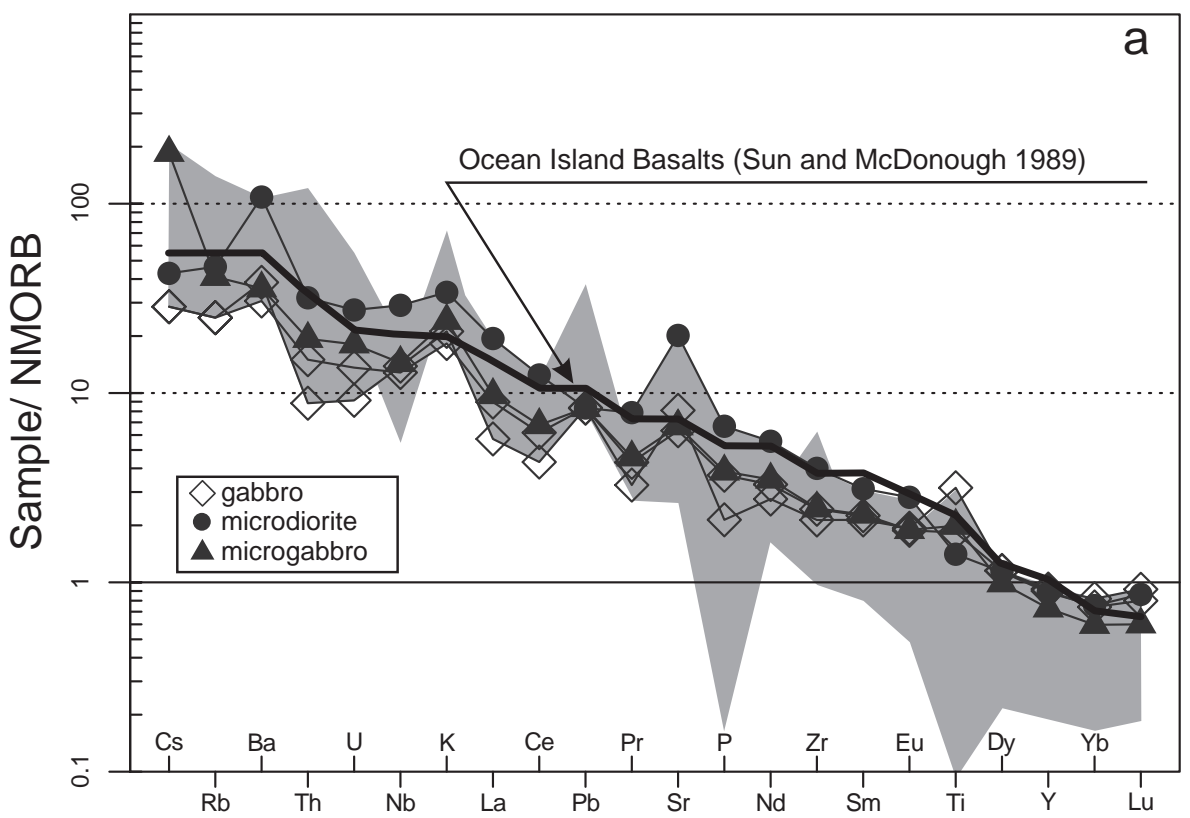

Fig. 8 N-MORB normalized multielement patterns for ultrabasic to basic (a) and intermediate to acidic rocks (b) from the Sagsai Pluton (normalization values from Sun and McDonough 1989). Thick black lines indicate the average composition of the Ocean Island Basalts (OIB; Sun and McDonough 1989) and Upper Continental Crust (Taylor and McLennan 1995), respectively.

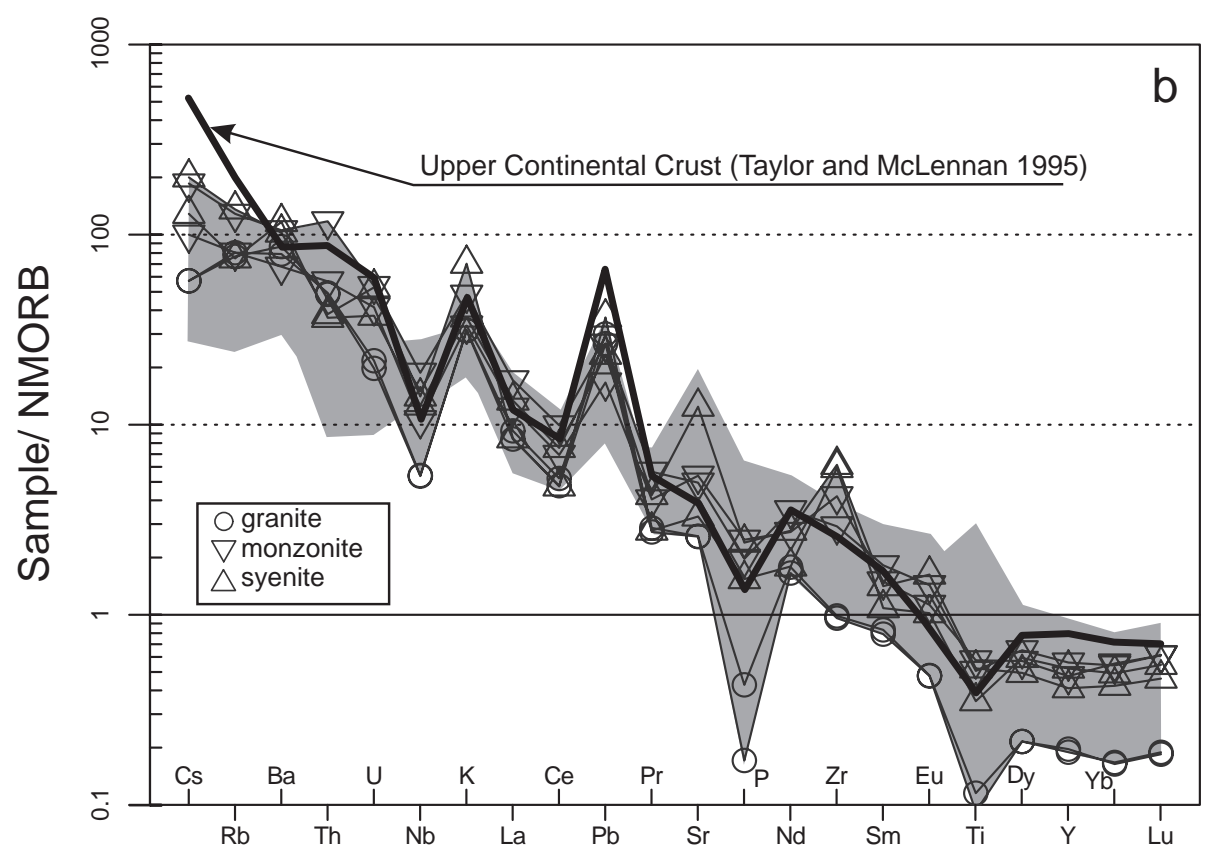

nism and depth of emplacement has not yet been studied. According to calculated $\mathrm{P}-\mathrm{T}$ conditions, we propose three main stages in the Sagsai Pluton evolution (Fig. 11).

Based on the thermobarometer of Ridolfi et al. (2010), the early cores of amphibole crystals (pargasite, $\mathrm{Si}=$ 5.74-5.95; $\mathrm{X}_{\mathrm{Mg}}=0.59-0.71$ ) from monzogabbro (sample V024a) started to grow at $>1000^{\circ} \mathrm{C}$ and $0.8-0.9 \mathrm{GPa}$. Hastingsite to ferrohornblende rims indicate significantly lower temperatures $\left(740-881^{\circ} \mathrm{C}\right.$, Tab. 5) obtained by plagioclase-hornblende thermometry (Holland and Blundy 1994). Pressures calculated from amphibole rims are also significantly lower $(0.5-0.6 \mathrm{GPa})$, based on the barometer of Anderson and Smith (1995).
The ensuing magma mixing with crustal melts and final crystallization of MME (V027c) occurred at P-T conditions $\left(723-827^{\circ} \mathrm{C}\right.$ and $\left.0.5-0.6 \mathrm{GPa}\right)$ similar to those of the migmatite xenoliths partial melting (Fig. 11 , sample P048b) $\left(736 \pm 74{ }^{\circ} \mathrm{C}\right.$ and $0.6 \pm 0.2 \mathrm{GPa}$ as calculated with THERMOCALC, Holland and Powell 1998).

The $\mathrm{P}-\mathrm{T}$ conditions of the Sagsai Pluton final emplacement were calculated from syenite sample V027b at 596 to $671^{\circ} \mathrm{C}$ and $0.4-0.5 \mathrm{GPa}$, using the Amp-Pl thermometer of Holland and Blundy (1994) and amphibole barometer of Anderson and Smith (1995). Based on the thermobarometer of Ridolfi et al. 


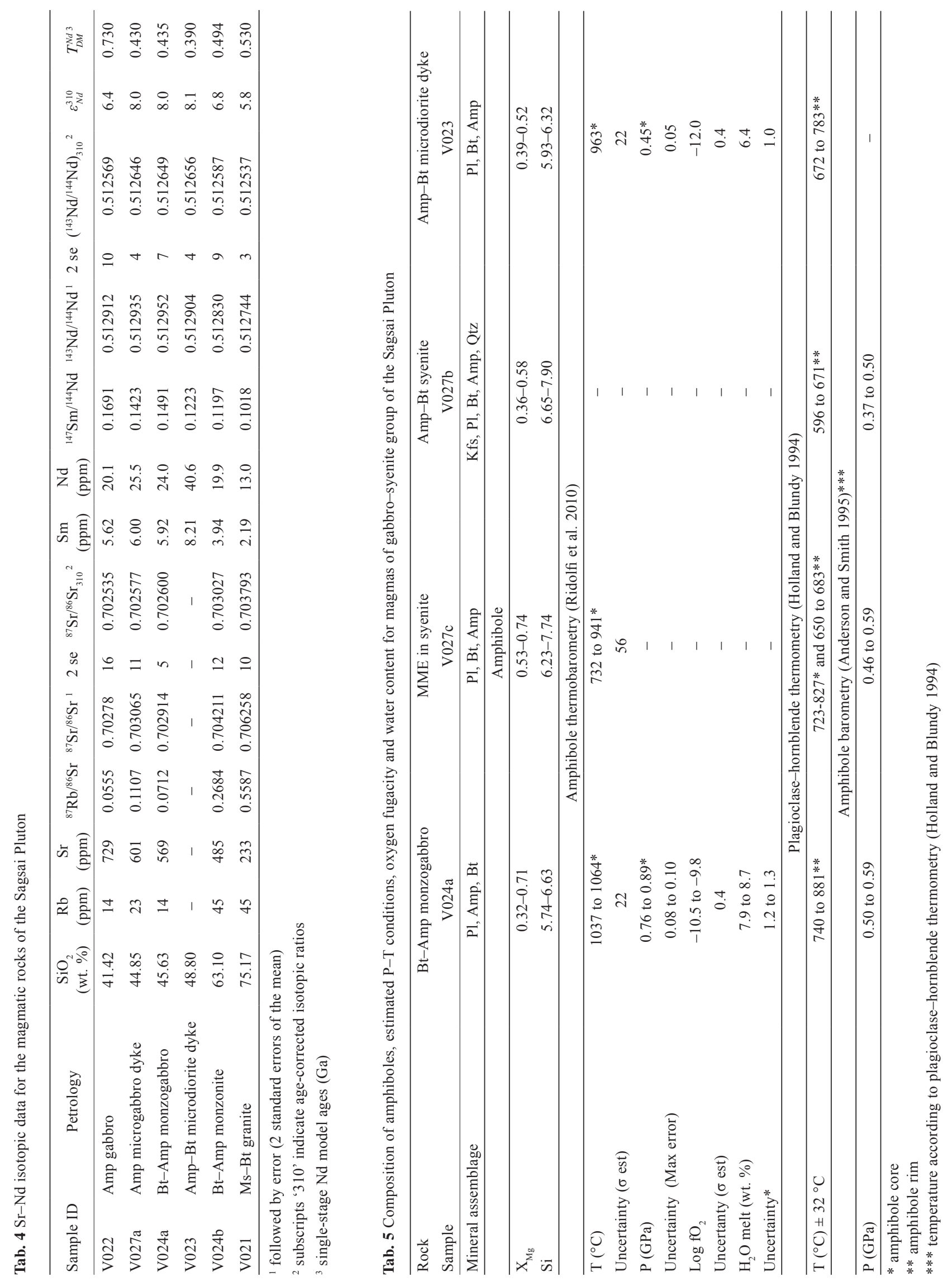


Fig. 9 Chondrite-normalized REE patterns (normalization values from Boynton 1984).

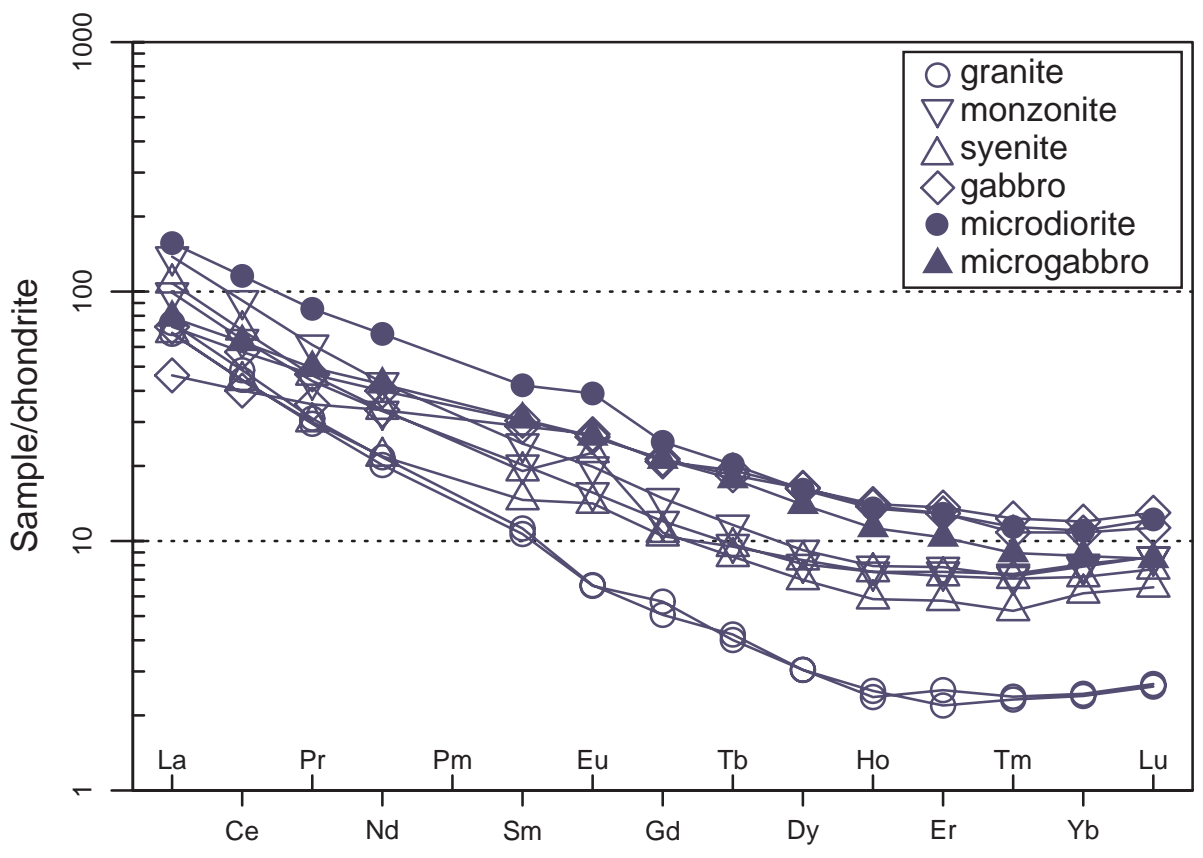

\section{Discussion}

(2010), the amphibole from microdiorite dyke (V023) crystallized under similar pressure $(0.5 \mathrm{GPa})$ as the surrounding syenite. These results are consistent with the $\mathrm{P}-\mathrm{T}$ conditions calculated for mineral assemblage of cordierite-biotite and biotite-chlorite schists in the contact aureole (Fig. 11). Ti-in-biotite thermometer (sample D026, Henry et al. 2005) indicates that metamorphic grade increases from the biotite zone $\left(548 \pm 9^{\circ} \mathrm{C}\right.$, sample D055a) to the cordierite zone $\left(637 \pm 8^{\circ} \mathrm{C}\right.$, sample D026).
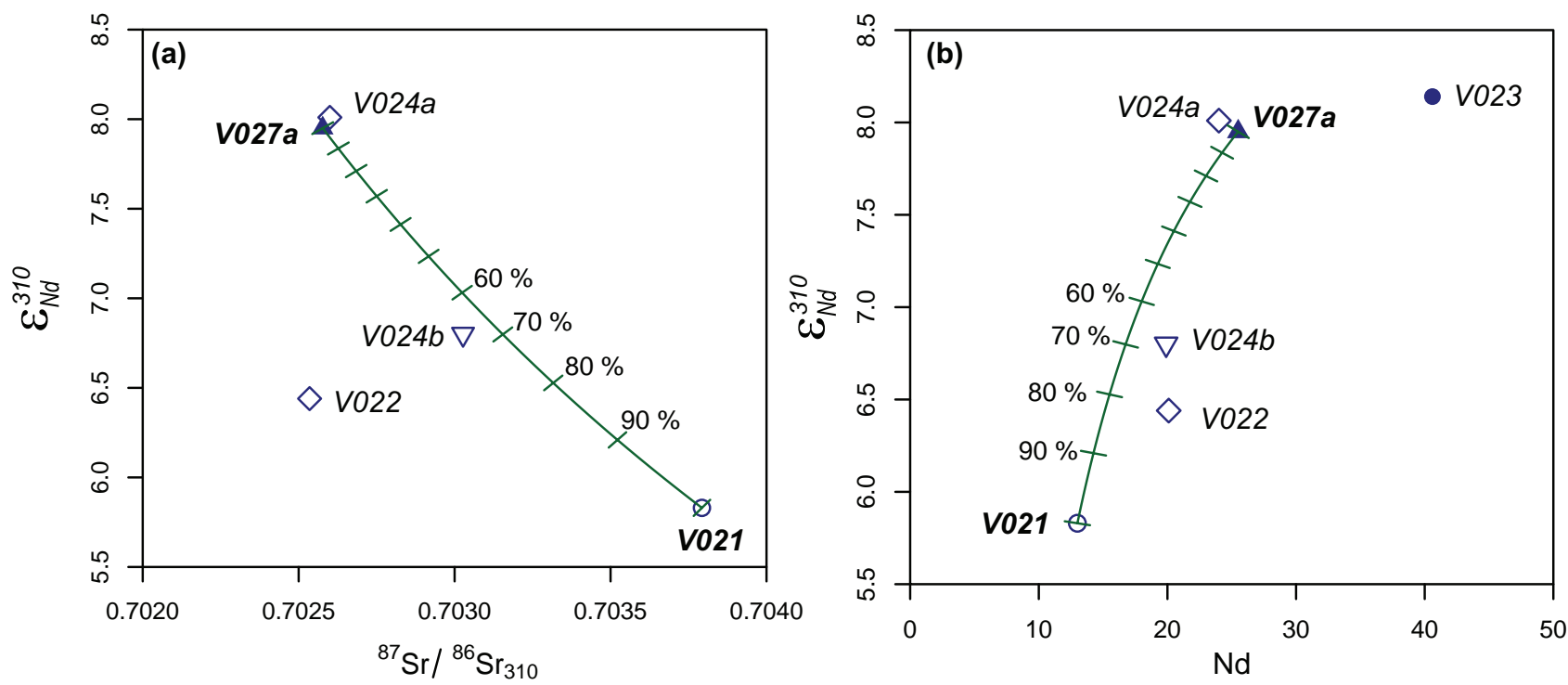

Fig. $10 \mathrm{Sr}-\mathrm{Nd}$ isotope geochemistry of the Sagsai Pluton. $\mathbf{a}-{ }^{87} \mathrm{Sr} /{ }^{86} \mathrm{Sr}_{310}-\varepsilon_{N d}^{310}$ plot. $\mathbf{b}-\mathrm{Nd}-\varepsilon_{N d}^{310}$ plot. Binary mixing hyperbolae in both cases indicate wt. \% of the assumed acid end-member (V021) mixed with a basic magma with a composition of the dyke V027a (see Janoušek et al. 2016 for the principles and code employed). Moreover, Fig. 10b confirms an important role for closed-system fractional crystallization, with or without crystal accumulation, of the basic magmas (V023, V027a, V024a). For explanation, see text. 


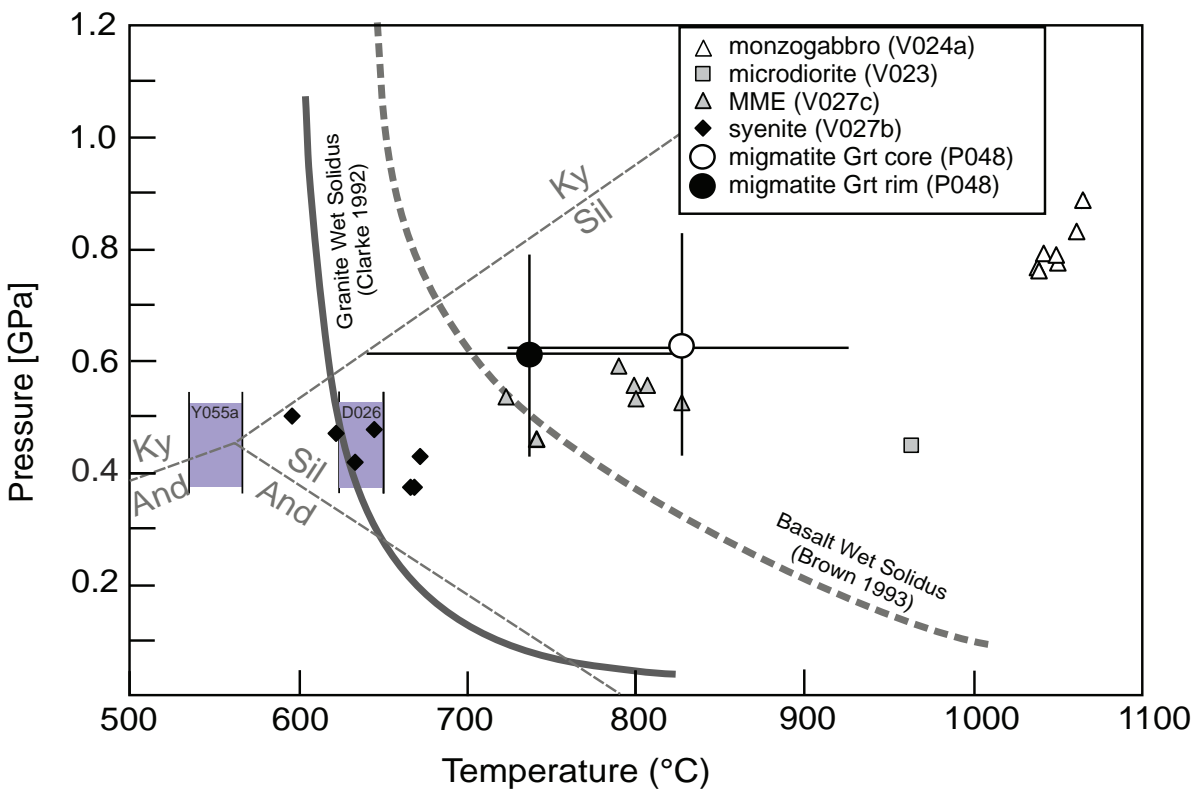

Fig. 11 Crystallization conditions for the selected igneous rocks from the Sagsai Pluton estimated based on amphibole geothermobarometry (Ridolfi et al. 2010). The P-T conditions of metamorphic rocks were estimated for garnet-bearing assemblages in the xenolith P047 by THERMOCALC (Holland and Powell 1998) and for the rocks from contact aureole (samples D026, Y055a) by the Ti-in-biotite thermometer (Henry et al. 2005). The position of the $\mathrm{Al}_{2} \mathrm{SiO}_{5}$ triple point is from Pattison (1992). were little modified by fractionation since they were derived from a mantle source. Their N-MORB normalized trace-element (Fig. 8) and chondrite-normalized REE patterns (Fig. 9) are typical of OIB magmas generated in an intraplate setting (e.g. Sun and McDonough 1989; Wilson 1989; Morata et al. 2005).

Indeed, the samples of ultrabasic and basic rocks fall within the within-plate basalts fields (Fig. 12a-b) in the discrimination diagrams $\mathrm{Zr} / 4-2 \times \mathrm{Nb}-\mathrm{Y}$ (Meschede 1986) and Th-Hf/3-Nb/16 (Wood 1980). Negligible, if any, crustal contamination of the basic melt is confirmed by relatively high $\mathrm{Nb} / \mathrm{La}(0.8-1.4)$ and $\mathrm{Nb} / \mathrm{Th}(14.5-30.5)$ ratios (Ewart et al. 1988; Kieffer et al. 2004). Moreover, any significant contamination by old and/or mature continental crust can be ruled out based on the primitive whole-rock $\mathrm{Sr}-\mathrm{Nd}$ and zircon $\mathrm{Hf}$ isotopic signatures that are close to the NMORB source at $310 \mathrm{Ma}$.

Discrimination diagrams (Harris et al. 1986; Schandl and Gorton 2002) indicate within-plate geotectonic setting also for all intermediate and acid rocks (Fig. 12cd). Syenite and quartz monzogranite samples are high in total alkalis. Although ratio $10000 \times \mathrm{Ga} / \mathrm{Al}(2.2-2.6)$ is relatively low, elevated $\mathrm{Na}_{2} \mathrm{O}+\mathrm{K}_{2} \mathrm{O}$ (6.9-10.1 wt. \%), $\mathrm{Zr}$ (216-455 ppm) and $\mathrm{Nb}(24-44 \mathrm{ppm})$ contents demonstrate affinity to A-type granitoids (Fig. 12e-f; Whalen et al. 1987; Eby 1990; King et al. 1997). However, the petrogenesis and geotectonic setting of A-type granitoids is ambiguous as they can form via numerous processes in contrasting tectonic environments (Bonin 2007, 2008; Magna et al. 2010) such as post-collisional extension (Foland and Allen 1991; Hong et al. 1996), mantle plume (Zhang CL and Zou 2013), back-arc (Espinoza et al. 2008), or ridge subduction settings (Bonin 2007, 2008; Anma et al. 2009). According to the relatively high $\mathrm{Nb} / \mathrm{Y}$ ratios $(1.8-2.8)$ the studied intermediate and acid rocks can be classified as $A_{1}$-type (Eby 1992). This group has been characterized as continental rift-related granitoids coming from OIB-like sources.

According to chemical composition can be granites of the Sagsai Pluton interpreted as a product of a crustallyderived, slightly peraluminous melt crystallization. The relatively low $\mathrm{A} / \mathrm{CNK}$ values $(<1.12), \mathrm{Rb} / \mathrm{Sr}(<0.3)$ and $\mathrm{Rb} / \mathrm{Ba}(<0.1)$ as well as high $\mathrm{CaO} / \mathrm{Na}_{2} \mathrm{O}(0.31-0.34)$ in granites are typical of magmas generated by partial melting of feldspar-rich psammitic rocks or orthogneisses (Sylvester 1998; Jung and Pfänder 2007).

The relatively low depleted-mantle $\mathrm{Nd}$ model ages even for the granite sample $(\sim 0.53 \mathrm{Ga})$ and the presence of the negative $\mathrm{Nb}$ anomalies in the NMORB-normalized spiderplots (most likely inherited from the source of the granitic melts; e. g. Janoušek et al 2010) are consistent with a model of partial melting of a primitive and young crust (immature metasediments or intermediate igneous rocks). The most plausible source for granite group of the

Fig. 12 Geotectonic discrimination diagrams for basic to ultrabasic ( $a-b)$ and intermediate to acid $(\mathrm{c}-\mathrm{d})$ rocks from Sagsai Pluton. a - Ternary diagram $\mathrm{Zr} / 4-2 \times \mathrm{Nb}-\mathrm{Y}$ (Meschede 1986): AI-AII: within-plate alkali basalts; AII-C: within-plate tholeiitic basalts; B: P-type mid-oceanic ridge basalts; D: N-type mid-oceanic ridge basalts; $\mathrm{C}-\mathrm{D}$ : volcanic arc. b - Th-Hf/3-Nb/16 ternary diagram (Wood 1980): N-MORB: normaltype mid-oceanic ridge basalts; E-MORB (WPT): enriched mid-oceanic ridge basalts (within-plate tholeiites); WPA: within-plate alkali basalts; CAB: calc-alkaline basalts; IAT: island-arc tholeiites. c - Ternary diagram Hf-Rb/30-3×Ta (Harris et al. 1986): Group 2: syn-collisional peraluminous intrusions, Group 3: late or post-collisional calc-alkaline intrusions, VA: Volcanic Arc, WP: Within Plate. d - Geotectonic discrimination diagram Th/Yb vs. Ta/Yb (Schandl and Gorton 2002): WPB: within-plate basalts, MORB: mid-ocean ridge basalts. $\mathbf{e}-\mathrm{Nb}$ vs. $10000 \times \mathrm{Ga} / \mathrm{Al}$ diagram (Whalen et al. 1987). f $-\mathrm{Y}-\mathrm{Nb}-\mathrm{Ce}$ triangular diagram showing for the A-type granites subdivision (Eby 1992). 

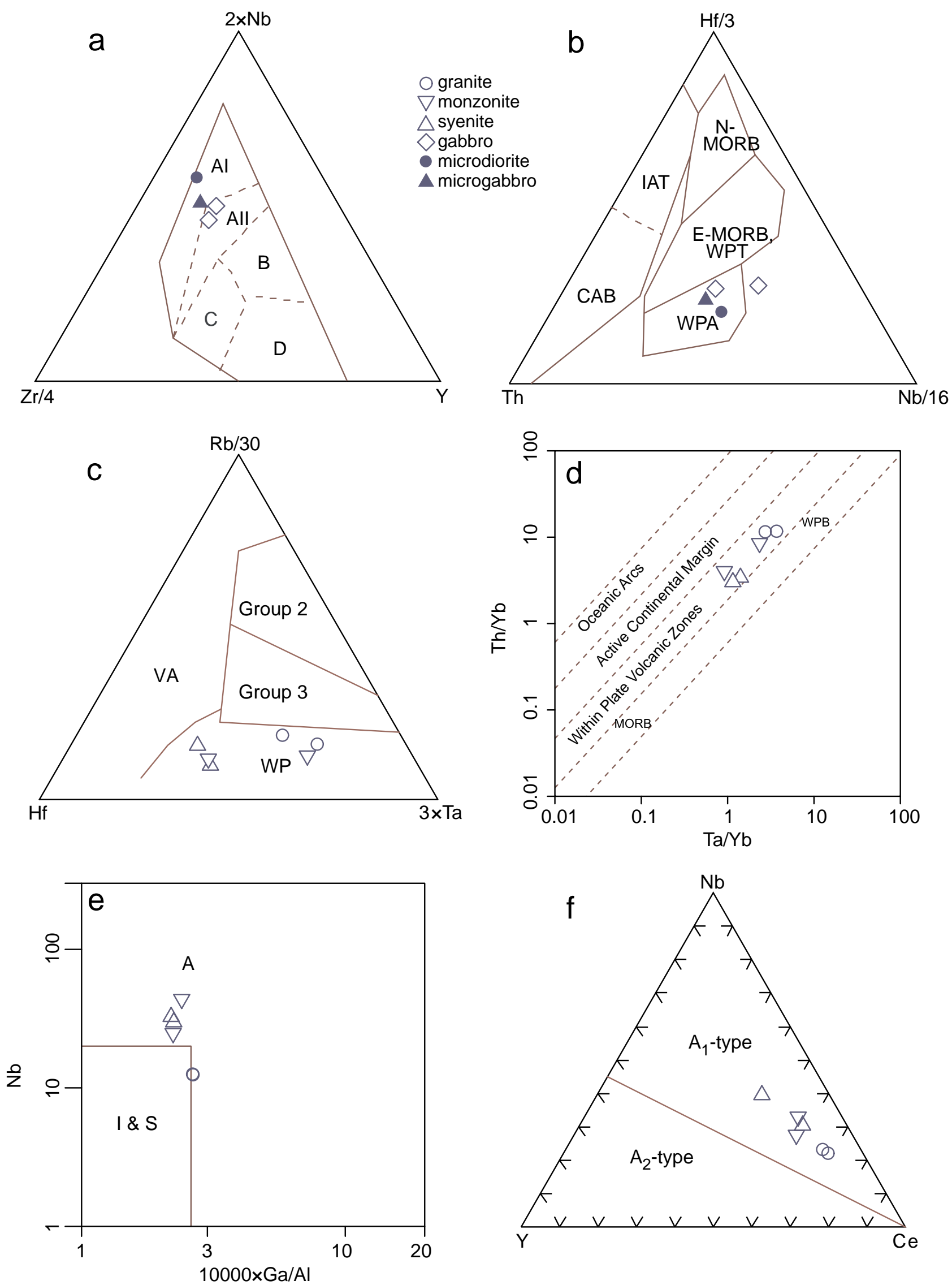
Sagsai Pluton thus would be a former Early Palaeozoic (? Cambrian) oceanic arc.

\subsection{Magma evolution}

Petrography with major- and trace-element variations indicate that fractional crystallization occurred during ascent of the basic magma. Sharp decrease in $\mathrm{Dy} / \mathrm{Yb}$ ratio (2.5 to 2.1) with increasing $\mathrm{SiO}_{2}$ is compatible with amphibole fractionation (Davidson et al. 2007). In addition, some fractionation of clinopyroxene is indicated by the continuously decreasing $\mathrm{CaO} / \mathrm{Al}_{2} \mathrm{O}_{3}(0.3-0.5$; not shown) with increasing $\mathrm{SiO}_{2}$ (e. g. Fan et al. 2008).

Petrographic observations and geochemical data suggest that hybridization between crustal and mantle-derived melts was significant in the genesis of syenites and quartz monzogranites. Its importance is documented by the abundance of MME commonly with chilled margins (e.g., Sparks et al. 1977; Didier and Barbarin 1991; Barbarin 2005; Blundy and Sparks 1992; Chen et al. 2009) as well as by the presence of some microtextures (e.g., Gamble 1979; Vernon 1984; Hibbard 1991; Janoušek et al. 2004; Słaby and Martin 2008). For instance, resorbed more calcic, weakly zoned cores $\left(\mathrm{Ab}_{43-56}\right)$ of plagioclase megacrysts in the MME are overgrown by oligoclase $\left(\mathrm{Ab}_{74-81}\right)$ rims. This zonation marks changes in plagioclase stability as a consequence of magma mixing (e.g., Vernon, 1991; Janoušek et al. 2000, 2004; Castro 2001; Müller et al. 2005). Acicular crystals in the MME may also indicate strong undercooling of the mafic system due to magma mixing (Hibbard 1991).

The continual increase in $\mathrm{CaO} / \mathrm{Na}_{2} \mathrm{O}$ ratios simultaneously with the content of mafic component in monzonite melt indicate that composition of the felsic rocks could have been also modified through mixing of basic with acid magmas (Sylvester 1998). More importantly, a significant role for interaction of basic and acid magmas derived from contrasting sources is given by the $\mathrm{Sr}-\mathrm{Nd}$ isotopic variation (Fig. 10a-b). The simple modelling of binary mixing indicates that the quartz monzonite V024b could have been produced by binary mixing of over 60 wt. \% of granitic magma resembling V021 with less than 40 wt. \% of a basic magma with a composition of the dyke V027a.

Hybrid origin of the two dated quartz monzonites is also in line with the presence of zircon domains giving a broad range of in-situ $\varepsilon_{H f}^{t}$ values ( +3.7 to +12.1 , Fig. 13). Hafnium isotopic compositions $(+4.1$ to +13.8$)$ of the xenocrystic zircons are exactly consistent with the composition of zircons from rocks in the western Tseel Terrane (Jiang et al. 2012).

In both $\mathrm{Sr}-\mathrm{Nd}$ isotopic diagrams (Fig. 10a-b), the gabbro V022 plots off trend, but close to sample V024b, perhaps indicating that it could be a cumulate from a similar hybrid quartz monzonitic magma. Lastly, the variation in the $\mathrm{Nd}-\varepsilon_{N d}^{310}$ plot (Fig. 10b) confirms important role for closed-system fractional crystallization of the basic magmas (V023, V027a, V024a).

\subsection{Emplacement and P-T evolution of the Sagsai Pluton}

Field and petrological relationships indicate that the Sagsai Pluton was emplaced as a sequence of three separate magma pulses. The gabbro intruded during first phase and was followed by syenites and quartz monzonites (phase 2) which contain abundant MME.

During phase 1 (c. $322 \pm 2 \mathrm{Ma}$ ) intruded mantle-derived melts into the middle crust (at a depth of about 30 $\mathrm{km}$ ), causing partial melting of the surrounding metasediments. The presence of actinolite/magnesiohornblende symplectites in the central parts some of the amphibole grains suggests a possible former presence of clinopyroxene probably as the result of low $\mathrm{H}_{2} \mathrm{O}$ activity at the early stages of crystallization. Nevertheless dominant mafic mineral in the gabbro is amphibole characterized by high $\mathrm{X}_{\mathrm{Fe}}$ and Si rims. This chemical zoning is typical of crystallization during magma mixing and fractionation (e.g. Erdmann et al. 2014). Chemical composition of mafic rocks and their amphibole may be interpreted in terms of a closed-system fractional crystallization, with, or without, crystal accumulation, as a main process. However, significant difference in calculated temperatures between amphibole cores and rims (1037-1064 vs. $\left.740-827^{\circ} \mathrm{C}\right)$ in

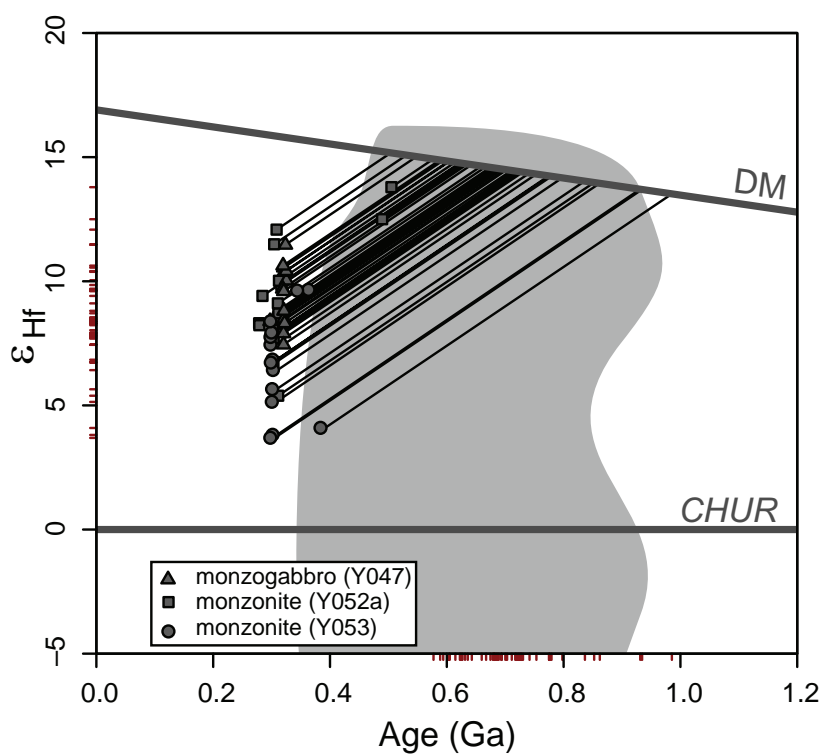

Fig. 13 Hafnium isotopic growth diagram for rocks of the gabbro-syenite group of the Sagsai Pluton. The extra ticks on the $\mathrm{x}$ axis denote the "crustal" Hf model ages $\left(T_{D M}^{C}\right)$, while those on the y axis are $\varepsilon_{H f}^{t}$ values. Grey area represents crystallization ages and Hf isotopic compositions for paragneisses, granites, granitic gneisses and volcanogenic rocks in the Tseel Terrane (Jiang et al. 2012). 
the gabbro can be also explained as result of interaction with cooler acid magma generated by partial melting of surrounding metasediments when the mafic magma was already partly crystallized. This is also in line with presence of discontinuous zoning in the plagioclase.

Syenites to quartz monzonites with abundant MME represent second phase of the Sagsai Pluton evolution. The magma interaction with crustal melts, comingling and crystallization of MME occurred at a depth of c. 20 $\mathrm{km}$ as indicate $\mathrm{P}-\mathrm{T}$ data obtained for the MME. The petrological data from syenite and the metamorphic aureole show that final emplacement occurred at c. 14-19 km. Intrusive ages for two samples of these rocks are $307 \pm 1$ $\mathrm{Ma}$ and $309 \pm 2 \mathrm{Ma}$. Injections of aplite, microdiorite and microgabbro dykes followed the syenites crystallization. These dykes are, on the other hand, crosscut by leucogranitic veins.

The rocks of the granite group show mineralogical and geochemical features that are characteristic of crustally derived magmas. Predominant, slightly peraluminous calc-alkaline granites with migmatite xenoliths are products of partial melting of psammitic rocks or orthogneisses.

\subsection{Geodynamic context}

Kozlovsky et al. (2015) advocated two models for the formation of Palaeozoic alkaline massifs in the SW Mongolia: (1) influence of the Tarim mantle plume on the lithosphere of the Central Asian Orogenic Belt or (2) slab break-off after blocking the subduction as a consequence of terrane accretion. The magmas generated in both cases would have similar geochemical signatures.

The studied basic rocks show an OIB-like chemistry, and all rock types share a within-plate geochemical signature $(\mathrm{Th} / \mathrm{Hf}=0.3-2.9, \mathrm{Th} / \mathrm{Ta}=0.5-4.4)$. Mainly relatively short interval between final closure of the basins of the Palaeo-Asian Ocean (latest arc-type magmatic rocks in the Gobi Altai area were emplaced at c. $332 \mathrm{Ma}$, Kozlovsky et al. 2015) demonstrates the suitability of a slab break-off model (Davies and von Blanckenburg 1995) for genesis of the Sagsai Pluton (initial stage of magmatism dated at $322 \pm 2 \mathrm{Ma}$ ).

The Sagsai Pluton belongs to a series of Late Carboniferous to Permian granitoids which form a linear E-W belt along the contact of the Mongol Altai and Trans-Altai tectonic zones (Kovalenko et al. 2006; Guy et al. 2014a). Geophysical study of Guy et al. (2014b) has shown that this tectono-magmatic zone spatially coincides with a strong, $c$. 15-20 km deep magnetic lineament. The analysis of magnetic lineaments in SW Mongolia also demonstrates that the zones of magnetic highs coincide with other E-W trending Late Paleozoic volcano-plutonic provinces previously defined by Kovalenko et al. (2006) as continental rifts related to Pacific-type geodynamic processes and protracted activity of mantle plumes (Yarmolyuk et al. 2014). Indeed the geophysical lineaments and magmatic zones can be interpreted as tectono-magmatic deformation zones deeply rooted in the lithosphere that probably channelled mantle-derived magmas (Guy et al. 2015). Our data confirm the idea that Late Carboniferous was a period of elevated thermal structure at the lithospheric scale, but the crust was molten heterogeneously leading to localized emplacement of magmas along E-W oriented lineaments. The Late Carboniferous magmatism in the Mongolian Altai was generally related to the final closure of remnant oceanic domain further south as proposed by e.g. Economos et al. (2012), Guy et al. (2014a, b) or Xiao et al. (2015). However, the most plausible setting for formation of mafic and felsic rocks of the Sagsai Pluton was already in a post-collisional extension geodynamic regime, perhaps shortly after the slab break-off (e. g. Zhang X et al. 2011).

\section{Conclusions}

Sagsai Pluton intruded the low-grade volcano-sedimentary complex of the Cambrian Tugrug Fm. in the Sagsai river valley SW of Tsogt soum (SE Mongolian Altai). This oval body $(\sim 9 \times 12 \mathrm{~km})$ is composed mainly of amphibole monzogabbros to quartz diorites, biotite to amphibole-biotite syenites to quartz monzonites. It was intruded by anatectic muscovite-biotite granites along the western rim. The Sagsai Pluton resulted from the sub-contemporaneous emplacement of three distinct magma batches. Still, all rock types share a within-plate geochemical signature.

1) Petrologic, geochemical and isotopic data demonstrate that the more basic types show an OIB-like chemistry. Positive zircon $\varepsilon_{H f}^{t}$ values suggest a juvenile magma source. Amphibole in the gabbro started to grow at $>$ $1000^{\circ} \mathrm{C}$ and $0.8-0.9 \mathrm{GPa}$. The mafic magmas intruded into higher levels of the Cambrian volcano-sedimentary crust at $0.5-0.6 \mathrm{GPa}$. Emplacement of amphibole gabbro (322 $\pm 2 \mathrm{Ma}$ ) caused the partial melting of the surrounding metasediments as indicated by $\mathrm{P}-\mathrm{T}$ conditions estimated for the migmatite xenoliths.

2) Chemical composition of rock-forming minerals and mineral assemblage of syenites to quartz monzonites document emplacement at shallower crustal levels $(0.4-0.5 \mathrm{GPa})$. The mafic melt has also intruded into a partly crystallized syenite magma chamber as shown by $\mathrm{P}-\mathrm{T}$ conditions obtained for MME. The abundant MME enclosed by syenites to quartz monzonites are taken as an evidence of magma mingling and mixing. Laser-ablation ICP-MS U-Pb zircon ages for two samples of quartz monzonites, identical within error 
$(307 \pm 1 \mathrm{Ma}$ and $309 \pm 2 \mathrm{Ma}$ ), are interpreted as an emplacement age.

3) Small intrusions of slightly peraluminous muscovitebiotite granites, derived by partial melting of feldspar-rich crustal source, represent the final magmatic event within the pluton.

Acknowledgements. We are thankful to two anonymous reviewers as well as the handling editor O. Gerel for their critical review of the draft manuscripts. We are indebted to P. Gadas and R. Čopjaková (Institute of Geological Sciences, Masaryk University) for the electron microprobe analyses, K. Hrdličková for her assistance during the manuscript preparation and V. Erban (Czech Geological Survey) for $\mathrm{Sr}$ and $\mathrm{Nd}$ isotope analyses. This study was supported by the project of Czech National Grant Agency GACR P210-12-2205 and 100 Talents Program of the Chinese Academy of Sciences to Y.D. Jiang.

Electronic supplementary material. Representative electron-microprobe analyses of amphibole, feldspars and biotite from the Sagsai Pluton, as well as LA-ICP-MS analytical data for dated zircons, are available online at the Journal web site (http://dx.doi.org/10.3190/jgeosci.207).

\section{References}

Amelin Y, Lee DC, Halliday AN, Pidgeon RT (1999) Nature of the Earth's earliest crust from hafnium isotopes in single detrital zircons. Nature 399: 252-255

Anderson JL, Smith DR (1995) The effects of temperature and $\mathrm{fO}_{2}$ on the $\mathrm{Al}$-in-hornblende barometer. Amer Miner 80: 549-559

Anma R, Armstrong R, Orihashi Y, Ire SI, Shin KC, Kon Y, Komiya T, Ota T, Kagashima SI, Shibuya T, Yamamoto S, Veloso EE, Fanning M, Hervé F (2009) Are the Taitao granites formed due to subduction of the Chile ridge? Lithos 113: 246-258

Badarch G, Cunningham WD, Windley BF (2002) A new terrane subdivision for Mongolia: implications for the Phanerozoic crustal growth of central Asia. J Asian Earth Sci 21: 87-110

BARBARIN B (2005) Mafic magmatic enclaves and mafic rocks associated with some granitoids of the central Sierra Nevada Batholith, California: nature, origin, and relations with the hosts. Lithos 80: 155-177

Blichert-Toft J, Chauvel C, Albarède F (1997) Separation of $\mathrm{Hf}$ and $\mathrm{Lu}$ for high-precision isotope analysis of rock samples by magnetic sector-multiple collector ICP-MS. Contrib Mineral Petrol 127: 248-260

Blundy JD, Sparks RSJ (1992) Petrogenesis of mafic inclusions in granitoids of the Adamello Massif, Italy. J Petrol 33: 1039-1104
Bonin B (2007) A-type granites and related rocks: evolution of a concept, problems and prospects. Lithos 97: 1-29

Bonin B (2008) Death of super-continents and birth of oceans heralded by discrete A-type granite igneous events: the case of the Variscan-Alpine Europe. J Geosci 53: $237-252$

Boynton WV (1984) Cosmochemistry of the rare earth elements: meteorite studies. In: HENDERSON PE (ed) Rare Earth Element Geochemistry. Elsevier, Amsterdam, pp 63-114

Brown M (1993) P-T-t evolution of orogenic belts: J Geol Soc, London 150: 227-241

Buriánek D, Hanžl P, Budil P, Gerdes A (2012) Evolution of the Early Permian volcanic-plutonic complex in the western part of the Permian Gobi-Altay Rift (Khar Argalant Mts, SW Mongolia). J Geosci 57: 105-126

CASTRO A (2001) Plagioclase morphologies in assimilation experiments: implications for disequilibrium melting in the generation of granodiorite rocks. Mineral Petrol 71: 31-49

Chen B, Chen ZC, JAhn BM (2009) Origin of mafic enclaves from the Taihang Mesozoic Orogen, North China Craton. Lithos 110: 343-358

Chernov EE, Kovalenko DV (2008) New paleomagnetic data on Carboniferous-Permian geological complexes of Mongolia. Dokl Earth Sci 420: 551-553

Clarke DB (1992) Granitoid Rocks. Chapman Hall, London, pp 1-283

Davidson J, Turner S, Handley H, Macpherson C, Dosseto A (2007) Amphibole "sponge" in arc crust? Geology 35: 787-790

Davies JH, von Blanckenburg F (1995) Slab breakoff: a model of lithosphere detachment and its test in the magmatism and deformation of collisional orogens. Earth Planet Sci Lett 129: 85-102

Dergunov AB (2001) Tectonics, Magmatism, and Metallogeny of Mongolia. Routledge, London, pp 1-288

Didier J, Barbarin B (1991) (eds) Enclaves and Granite Petrology. Elsevier, Amsterdam, pp 1-625

DROOP GTR (1987) A general equation for estimating $\mathrm{Fe}^{3+}$ concentrations in ferromagnesian silicates using stoichiometric criteria. Mineral Mag 51: 431-435

Economos RC, Paterson SR, Said LO, Ducea MN, AnderSON JL, PADILla AJ (2012) Gobi-Tianshan connections: field observations and isotopes from an early Permian arc complex in southern Mongolia. Geol Soc Amer Bull 124: $1688-1701$

Eвy GN (1990) The A-type granitoids: a review of their occurrence and chemical characteristics and speculations on their petrogenesis. Lithos 26: 115-134

Eвy GN (1992) Chemical subdivision of the A-type granitoids: petrogenetic and tectonic implications. Geology 20: 641-644

Erdmann S, Martle C, Pichavant M, Kushnir A (2014) Amphibole as an archivist of magmatic crystallization 
conditions: problems, potential, and implications for inferring magma storage prior to the paroxysmal 2010 eruption of Mount Merapi, Indonesia. Contrib Mineral Petrol 167:1016

Espinoza F, Morata D, Polve M, Lagabrielle Y, Maury RC, Guivel C, Cotton G, Bellon H, Suarez M (2008) Bimodal back-arc alkaline magmatism after ridge subduction; Pliocene felsic rocks from central Patagonia (47 $\left.{ }^{\circ} \mathrm{S}\right)$. Lithos 101: 191-217

Ewart A, Chappell BW, Menzies MA (1988) An overview of the geochemical and isotopic characteristics of the eastern Australian Cainozoic volcanic provinces. J Petrol, Special Lithosphere Issue: $225-273$

Fan WM, Zhang CH, Wang YJ, Guo F, Peng TP (2008) Geochronology and geochemistry of Permian basalts in western Guangxi province, southwest China: evidence for plume-lithosphere interaction. Lithos 102: 218-236

Foland KA, Allen JC (1991) Magma source for Mesozoic anorogenic granites of the White Mountain magma series, New England, USA. Contrib Miner Petrol 109: 195-221

Frost BR, Barnes CG, Collins WJ, Arculus RJ, Ellis DJ, Frost CD (2001) A geochemical classification for granitic rocks. J Petrol 42: 2033-2048

Gamble JA (1979) Some relationships between coexisting granitic and basaltic magmas and the genesis of hybrid rocks in the Tertiary central complex of Slieve Gullion, northeast Ireland. J Volcanol Geotherm Res 5: 297-316

Griffin WL, Belousova EA, Shee SR, Pearson NJ, O'Reilly SY (2004) Archean crustal evolution in the northern Yilgarn Craton: $\mathrm{U}-\mathrm{Pb}$ and $\mathrm{Hf}$-isotope evidence from detrital zircons. Precambr Res 131: 231-282

Guy A, Schulmann K, Clauer N, Hasalová P, Seltmann R, Armstrong R, Lexa O, Benedicto A (2014a) Late Paleozoic-Mesozoic tectonic evolution of the TransAltai and South Gobi zones in southern Mongolia based on structural and geochronological data. Gondwana Res 25: 309-337

Guy A, Schulmann K, Munschy M, Miehe JM, Edel JB, LEXA O (2014b) Geophysical constraints for terrane boundaries in southern Mongolia. J Geophys Res 119: 7966-7991

Guy A, Schulmann K, Janoušek V, Ští́pská P, Armstrong R, Belousova E, Dolgopolova A, Seltmann R, Lexa O, JIANG Y, HANŽL P (2015) Geophysical and geochemical nature of relaminated arc-derived lower crust underneath oceanic domain in southern Mongolia. Tectonics 34: 1030-1053

Hanžl P, Bat-Ulzi D, Rejchrt M, KošLer J, BolormaA K, HRDLIČKovÁ K (2008) Geology and geochemistry of the Palaeozoic plutonic bodies of the Trans-Altay Gobi, SW Mongolia: implications for magmatic processes in an accreted volcanic-arc system. J Geosci 53: 201-234

Harris NBW, Pearce JA, Tindle AG (1986) Geochemical characteristics of collision-zone magmatism. In: COWARD
MP, Ries AC (eds) Collision Tectonics. Geological Society London Special Publications 19: 67-81

Hastie AR, Kerr AC, Pearce JA, Mitchell SF (2007) Classification of altered volcanic island arc rocks using immobile trace elements: development of the Th-Co discrimination diagram. J Petrol 48: 2341-2357

Hendrix MS, Graham SS, Carroll AR, Sobel ER, Mc Knight CL, Schulein BJ, Wang Z (1992) Sedimentary record and climatic implications of recurrent deformation in the Tianshan: evidence from Mesozoic strata of the north Tarim, south Junggar and Turpan basins, northwest China. Geol Soc Am Bull 104: 53-79

Henry DJ, Guidotti CV, Thomson JA (2005) The Ti-saturation surface for low-to-medium pressure metapelitic biotite: implications for geothermometry and Ti-substitution mechanisms. Amer Miner 90: 316-328

HibBARD MJ (1991) Textural anatomy of twelve magmamixed granitoid systems. In: Didier J, BARBARIN B (eds) Enclaves and Granite Petrology. Elsevier, Amsterdam, pp 431-443

Holland TJB, Blundy J (1994) Non-ideal interactions in calcic amphiboles and their bearing on amphiboleplagioclase thermometry. Contrib Mineral Petrol 116: 433-447

Holland TJB, Powell R (1998) An internally consistent thermodynamic data set for phases of petrological interest. J Metamorph Geol 16: 309-343

Hong DW, Huang HZ, XIAo YJ, Xu HM, Jin MY (1995) Permian alkaline granites in central Inner Mongolia and their geodynamic significance. Acta Geol Sin 8: 27-39

Hong DW, WANG SG, HAN BF, JIN MY (1996) Post-orogenic alkaline granites from China and comparisons with anorogenic alkaline granites elsewhere. J Asian Earth Sci 30: 13-27

IrVINE TN, BARAGAR WRA (1971) A guide to the chemical classification of the common volcanic rocks. Can J Earth Sci 8: 523-548

JaCOBSEN SB, WasSERbURG GJ (1980) Sm-Nd isotopic evolution of chondrites. Earth Planet Sci Lett 50: 139-155

JAHN BM (2004) The Central Asian Orogenic Belt and growth of the continental crust in the Phanerozoic. In: Malpas J, Fletcher CJN, Aitchison JC (eds) Aspects of the Tectonic Evolution of China. Geological Society of London Special Publications 226: 73-100

J $\mathrm{AHN}_{\text {B }}$, WU F, CHEN B (2000) Massive granitoid generation in Central Asia: $\mathrm{Nd}$ isotope evidence and implication for continental growth in the Phanerozoic. Episodes 23: 82-92

Jahn BM, Litvinovsky BA, Zanvilevich AN, Reichow MK (2009) Peralkaline granitoid magmatism in the Mongolian-Transbaikalian Belt: evolution, petrogenesis and tectonic significance. Lithos 113: 521-539

Janoušek V, Bowes DR, Braithwaite CJR, Rogers G (2000) Microstructural and mineralogical evidence for limited 
involvement of magma mixing in the petrogenesis of a Hercynian high-K calc-alkaline intrusion: the Kozárovice granodiorite, Central Bohemian Pluton, Czech Republic. Trans Roy Soc Edinb, Earth Sci 91: 15-26

Janoušek V, Braithwaite CJR, Bowes DR, Gerdes A (2004) Magma-mixing in the genesis of Hercynian calc-alkaline granitoids: an integrated petrographic and geochemical study of the Sázava intrusion, Central Bohemian Pluton, Czech Republic. Lithos 78: 67-99

JANOUŠEK V, FARROW CM, ERBAN V (2006) Interpretation of whole-rock geochemical data in igneous geochemistry: introducing Geochemical Data Toolkit (GCDkit). J Petrol 47: 1255-1259

JaNOUŠEK V, KonopáseK J, Ulrich S, ERban V, TAJČMANOVÁ L, JEŘÁBEK P (2010) Geochemical character and petrogenesis of Pan-African Amspoort suite of the Boundary Igneous Complex in the Kaoko Belt (NW Namibia). Gondwana Res 18: 688-707

Janoušek V, Moyen JF, Martin H, Erban V, Farrow C (2016) Geochemical Modelling of Igneous Processes - Principles and Recipes in R Language. Bringing the Power of $\mathrm{R}$ to a Geochemical Community. SpringerVerlag, Berlin, Heidelberg, pp 1-346

Jiang Y, Sun M, Kröner A, Tumurkhuu D, Long X, Zhao G, Yuan C, XIaO WJ (2012) The high-grade Tseel Terrane in SW Mongolia: an Early Paleozoic arc system or a Precambrian sliver? Lithos 142-143: 95-115

JUNG S, PFäNDER JA (2007) Source composition and melting temperatures of orogenic granitoids: constraints from $\mathrm{CaO} / \mathrm{Na}_{2} \mathrm{O}, \mathrm{Al}_{2} \mathrm{O}_{3} / \mathrm{TiO}_{2}$ and accessory mineral saturation thermometry. Eur J Miner 19: 859-870

Kieffer B, Arndt N, Lapierre H, Bastien F, Bosch D, Pecher A, Yirgu G, Ayalew D, Weise D, Jerram DA, Keller F, Meugniot C (2004) Flood and shield basalts from Ethiopia: magmas from the African superswell. J Petrol 45: 793-834

King PL, White AJR, Chappell BW, Allen CM (1997) Characterisation and origin of aluminous A-type granites from the Lachlan Fold Belt, Southeastern Australia. J Petrol 38: 371-391

Kovalenko D, Chernov E (2008) Paleomagnetism of Carboniferous-Permian and early Jurassic geological complexes in Mongolia. Izvestiya Phys Solid Earth 44: 427-441

Kovalenko V, Yarmoluyk V, Sal'nikova E, Kozlovsky A, Kotov A, Kovach V, Savatenkov V, Vladykin N, Ponomarchuk V (2006) Geology, geochronology, and geodynamics of the Khan Bogd alkali granite pluton in southern Mongolia. Geotectonics 40: 450-466

Kozlovsky AM, Yarmolyuk VV, Travin AV, Sal'nikova EB, Anisimova IV, Plotkina YV, Savatenkov VM, FeDoseenko AM, Yakovleva SZ (2012) Stages and regularities in the development of Late Paleozoic anorogenic volcanism in the Southern Mongolia Hercynides. Dokl Earth Sci 445: 811-817
Kozlovsky AM, Yarmolyuk VV, Sal'nikova EB, Travin AV, Kotov AB, Plotkina JV, Kudryashova EA, SavatenKOV VM (2015) Late Paleozoic anorogenic magmatism of the Gobi Altai (SW Mongolia): tectonic position, geochronology and correlation with igneous activity of the Central Asian Orogenic Belt. J Asian Earth Sci 113: 524-541

Kröner A, Windley BF, Badarch G, Tomurtogoo O, Hegner E, Jahn BM, Gruschka S, Khain EV, Demoux A, WINGATE MTD (2007) Accretionary growth and crust formation in the Central Asian Orogenic Belt and comparison with the Arabian-Nubian Shield. In: HATCHER RD, Carlson MP, McBride JH, Martínez Catalán JR (eds) 4-D Framework of Continental Crust. Geological Society of America Memoirs 200: 181-209

Kuzmin MI, Yarmolyuk VV, Kravchinsky VA (2011) Phanerozoic within-plate magmatism of north Asia: absolute paleogeographic reconstructions of the African large low-shear-velocity province. Geotectonics 45 : 415-438

Leake BE, Wooley AR, Arps CES, Birch WD, Gilbert MC, Grice JD, Hawthorne FC, Kato A, Kisch HJ, KrivoviChev VG, Linthout K, Laird J, Mandarino J, Maresch WV, Nickel EH, Rock NMS, Schumacher JC, SMith JC, Stephenson NCN, WhitTAKer EJW, Youzhi G (1997) Nomenclature of amphiboles: report of the Subcommittee on Amphiboles of the International Mineralogical Association Commission on New Minerals and Mineral Names. Canad Mineral 35: 219-237

Li XH, Long WG, Li QL, Liu Y, Zheng YF, Yang YH, Chamberlain KR, Wan DF, Guo CH, Wang XC, Tao H (2010) Penglai zircon megacrysts: a potential new working reference material for microbeam determination of $\mathrm{Hf}-\mathrm{O}$ isotopes and $\mathrm{U}-\mathrm{Pb}$ age. Geost Geoanal Res 34: 117-134

Liew TC, Hofmann AW (1988) Precambrian crustal components, plutonic associations, plate environment of the Hercynian Fold Belt of Central Europe: indications from a $\mathrm{Nd}$ and $\mathrm{Sr}$ isotopic study. Contrib Mineral Petrol 98: $129-138$

Liu Y, Hu Z, Gao S, Günther D, Xu J, Gao C, Chen H (2008) In situ analysis of major and trace elements of anhydrous minerals by LA-ICP-MS without applying an internal standard. Chem Geol 257: 34-43

LuDwig KR (2003) User's Manual for Isoplot 3.00: A Geochronological Toolkit for Microsoft Excel. Berkeley Geochronological Center, Special Publications 4a: 155-179

Lugmair GW, Marti K (1978) Lunar initial ${ }^{143} \mathrm{Nd} /{ }^{144} \mathrm{Nd}$ : differential evolution line of the lunar crust and mantle. Earth Planet Sci Lett 39: 349-357

Machado N, Simonetti A (2001) U-Pb dating and Hf isotopic composition of zircons by laser ablation-MC-ICPMS. In: Sylvester P (ed) Laser-Ablation-ICPMS in the Earth Sciences: Principles and Applications. Mineralogical Association of Canada Short Courses 29: 121-146 
Magna T, Janoušek V, Kohút M, Oberli F, Wiechert U (2010) Fingerprinting sources of orogenic plutonic rocks from Variscan belt with lithium isotopes and possible link to subduction-related origin of some A-type granites. Chem Geol 274: 94-107

Mao JW, Franco P, Bernd L, Luo MC, Anita B (2014) Distribution of porphyry deposits in the Eurasian continent and their corresponding tectonic settings. J Asian Earth Sci 79: 576-584

Meschede M (1986) A method of discriminating between different types of mid-ocean ridge basalts and continental tholeiites with the $\mathrm{Nb}-\mathrm{Zr}-\mathrm{Y}$ diagram. Chem Geol 56: 207-218

MiddLEmost EAK (1994) Naming materials in the magma/ igneous rock system. Earth Sci Rev 37: 215-224

Míková J, Denková P (2007) Modified chromatographic separation scheme for $\mathrm{Sr}$ and $\mathrm{Nd}$ isotope analysis in geological silicate samples. J Geosci 52: 221-226

Morata D, Olivia C, De La Cruz R, SuÁrez M (2005) The Bandurrias gabbro: Late Oligocene alkaline magmatism in the Patagonian Cordillera. J South Am Earth Sci 18: 147-162

Morimoto N, Fabries J, Ferguson AK, Ginzburg IV, Ross M, Seifert FA, Zussman J, Aoki K, Gottardi G (1988) Nomenclature of pyroxenes. Amer Miner 73: 1123-1133

Müller A, Breiter K, Seltmann R, Pécskay Z (2005) Quartz and feldspar zoning in the Eastern Erzgebirge Pluton (Germany, Czech Republic): evidence of multiple magma mixing. Lithos 80: 201-227

PATTISON DRM (1992) Stability of andalusite and sillimanite and the $\mathrm{Al}_{2} \mathrm{SiO}_{5}$ triple point: constraints from the Ballachulish aureole, Scotland. J Geol 100: 423-446

Peccerillo A, Taylor SR (1976) Geochemistry of Eocene calc-alkaline volcanic rocks from the Kastamonu area, northern Turkey. Contrib Mineral Petrol 58: 63-81

Pin C, Zalduegui JFS (1997) Sequential separation of light rare-earth elements, thorium and uranium by miniaturized extraction chromatography: application to isotopic analyses of silicate rocks. Anal Chim Acta 339: 79-89

Pin C, Briot D, Bassin C, Poitrasson F (1994) Concomitant separation of strontium and samarium-neodymium for isotopic analysis in silicate samples, based on specific extraction chromatography. Anal Chim Acta 298: 209-217

Pouchou JL, Pichoir F (1985) "PAP" (Ф $\rho Z)$ procedure for improved quantitative microanalysis. In: ArMSTRONG JT (ed) Microbeam Analysis 1985: 104-106

Powell R, Holland TJB, (2008) On thermobarometry. J Metamorph Geol 26: 155-179

Rauzer AA, Zhanchiv DI, Golyakov VI, Ykhina IF, Ivanov IG, Tsukernik AB, Afonin VV, Smirnov IG, Bykhover VI, Kravtsev AV, Baatarkhuyag A, Skoryukin Mi, Khodikov IV, Mantsev NV, Okaemov SV, Mischin VA, ENKHSAJKHAN T (1987) Report on Results of Geological Survey on the scale of $1: 200,000$, Performed in South- east Part of the Mongolian Altay, Mongolian National Republic in 1983-1986. Tekhnoexport, Moscow, pp 1-352 (in Russian)

Ridolfi F, Renzulli A (2012) Calcic amphiboles in calcalkaline and alkaline magmas: thermobarometric and chemometric empirical equations valid up to $1,130^{\circ} \mathrm{C}$ and 2.2 GPa. Contrib Mineral Petrol 163: 877-895

Ridolfi F, Renzulli A, Puerini M (2010) Stability and chemical equilibrium of amphibole in calc-alkaline magmas: an overview, new thermobarometric formulations and application to subduction related volcanoes. Contrib Mineral Petrol 160: 45-66

Sandimirova GP, Plyusnin GS, Kovalenko VI, PakholChenko YuA, Goreglyad AV, Vladykin NV (1980) The age of the alkalic granites in Mongolia according to $\mathrm{Rb} /$ Sr data. Sov Geol Geophys 21: 129-132

Schandl ES, Gorton MP (2002) Application of high field strength elements to discriminate tectonic settings in VMS environments. Econ Geol 97: 629-642

Shand SJ (1943) Eruptive Rocks. Their Genesis, Composition, Classification, and Their Relation to Ore-Deposits with a Chapter on Meteorite, $2^{\text {nd }}$ edition. John Wiley \& Sons, New York, pp 1-444

Shi GH, Miao LC, Zhang FQ, Jian P, Fan WM, Liu DY (2004) The age and its regional tectonic implications of the Xilinhot A-type granites, Inner Mongolia. Chin Sci Bul 49: 384-389

SŁABy E, Martin H (2008) Mafic and felsic magma interaction in granites: the Hercynian Karkonosze Pluton (Sudetes, Bohemian Massif). J Petrol 49: 353-391

Söderlund U, Patchett PJ, Vervoort JD, Isachsen CE (2004) The ${ }^{176} \mathrm{Lu}$ decay constant determined by $\mathrm{Lu}-\mathrm{Hf}$ and $\mathrm{U}-\mathrm{Pb}$ isotope systematics of Precambrian mafic intrusions. Earth Planet Sci Lett 219: 311-324

Sparks RSJ, Sigurdsson H, Wilson L (1977) Magma mixing: a mechanism for triggering acid explosive eruptions. Nature 267: 315-318

Steiger RH, JäGER E (1977) Subcommission on Geochronology; convention on the use of decay constants in geoand cosmochronology. Earth Planet Sci Lett 36: 359-362

Sun SS, McDonough WF (1989) Chemical and isotopic systematics of oceanic basalts: implications for mantle composition and processes. In: SAUNDERS AD, NorRY MJ (eds) Magmatism in Ocean Basins. Geological Society of London Special Publications 42: 313-345

Sylvester PJ (1998) Post-collisional strongly peraluminous granites. Lithos 45: 29-44

ŞEnGör AMC, NatAL'In BA, Burtman VS (1993) Evolution of the Altaid tectonic collage and Paleozoic crustal growth in Eurasia. Nature 364: 299-307

Tanaka T, Togashi S, Kamioka H, Amakawa H, Kagami H, Hamamoto T, Yuhara M, Orihashi Y, Yoneda S, Shimizu H, Kunimaru T, Takahashi K, Yanagi T, NaKano T, Fujimaki H, Shinjo R, Asahara Y, Tanimizu M, 
Dragusanu C (2000) JNdi-1: a neodymium isotopic reference in consistency with La Jolla neodymium. Chem Geol 168: 279-281

TaYlor SR, McLennan SM (1995) The geochemical evolution of the continental crust. Rev Geophys 33: 241-265

Vernon RH (1984) Microgranitoid enclaves in granites - globules of hybrid magma quenched in a plutonic environment. Nature 309: 438-439

VERNON RH (1991) Interpretation of microstructures of microgranitoid enclaves. In: DIDIER J, BARBARIN B (eds) Enclaves and Granite Petrology. Elsevier, Amsterdam, pp 277-291

Vladykin NV, Kovalenko VI, Dorfman MD (1981) Mineralogical and Geochemical Peculiarities of Khan Bogd Massif of Alkaline Granites (MPR). Nauka, Moscow, pp 1-136 (in Russian)

Wasserburg GJ, Jacobsen SB, DePaolo DJ, McCulloch MT, Wen T (1981) Precise determination of $\mathrm{Sm} / \mathrm{Nd}$ ratios, $\mathrm{Sm}$ and Nd isotopic abundances in standard solutions. Geochim Cosmochim Acta 45: 2311-2324

Whalen JB, Currie KL, Chappell BW (1987) A-type granites - geochemical characteristics, discrimination and petrogenesis. Contrib Mineral Petrol 95: 407-419

WhITNEY DL, EvANs BW (2010) Abbreviations for names of rock-forming minerals. Amer Miner 95: 185-187

WiLSON M (1989) Igneous Petrogenesis. Unwin Hyman, London, pp 1-466

Windley BF, Alexeiev DV, Xiao WJ, Kröner A, Badarch G (2007) Tectonic models for accretion of the Central Asian Orogenic Belt. J Asian Earth Sci 164: 31-47

Wood DA (1980) The application of a Th-Hf-Ta diagram to problems of tectonomagmatic classification and to establishing the nature of crustal contamination of basaltic lavas of the British Tertiary Volcanic Province. Earth Planet Sci Lett 50: 11-30

Wu FY, Sun DY, Li HM, JAHN BM, WiLde S (2002) A-type granites in northeastern China: age and geochemical constraints on their petrogenesis. Chem Geol 187: 143-173

Wu FY, YANG YH, XIE LW, YANG JH, Xu P (2006) Hf isotopic compositions of the standard zircons and baddeleyites used in U-Pb geochronology. Chem Geol 234: 105-126

Xia X, Sun M, Geng H, Sun Y, Wang Y, Zhao G (2011) Quasi-simultaneous determination of $\mathrm{U}-\mathrm{Pb}$ and $\mathrm{Hf}$ isotope compositions of zircon by excimer laser-ablation multiple-collector ICPMS. J Analyt Atom Spectrom 26: 1868-1871

Xiao WJ, Windley BF, Hao J, Zhai M (2003) Accretion leading to collision and the Permian Solonker Suture, Inner Mongolia, China: termination of the Central Asian Orogenic Belt. Tectonics 22: 1069, doi: 10.1029/2002TC001484

Xiao WJ, Windley BF, Badarch G, Sun S, Li J, Qin K, WANG Z (2004) Palaeozoic accretionary and convergent tectonics of the southern Altaids: implications for the growth of Central Asia. J Geol Soc, London 161: 1-4

Xiao WJ, Han CM, Yuan C, Sun M, Lin SF, Chen HL, Li ZL, Li JL, Sun S (2008) Middle Cambrian to Permian subduction-related accretionary orogenesis of North Xinjiang, NW China: implications for the tectonic evolution of Central Asia. J Asian Earth Sci 32: 102-117

Xiao WJ, Windley BF, Sun SZ, Li J, Huang B, Han C, Yuan C, Sun M, Chen H (2015) A tale of amalgamation of three Permo-Triassic collage systems in Central Asia: oroclines, sutures, and terminal accretion. Annu Rev Earth Planet Sci 43: 477-507

Xixi Z, Coe R S, Yaoxiu Z, Haoruo W, Jie W (1990) New paleomagnetic results from northern China: collision and suturing with Siberia and Kazakhstan. Tectonophysics 181: 43-81

Yarmolyuk VV (1983) Late Palaeozoic Volcanism in the Continental Rift Structures of Central Asia. Nauka, Moscow, pp 1-198 (in Russian)

Yarmolyuk VV, KovalenKo VI (1991) Rift Magmatism of Active Continental Margins and Its Ore Potential. Nauka, Moscow, pp 1-263 (in Russian)

Yarmolyuk VV, Kovalenko VI (2001) Late Riphean breakup between Siberia and Laurentia: evidence from intraplate magmatism. Dokl Earth Sci 379: 525-528

Yarmolyuk VV, Kovalenko VI, Kozlovsky AM, Vorontsov AA, Savatenkov VM (2005) Late Paleozoic-Early Mesozoic rift system of Central Asia: composition of magmatic rocks, sources, order of formation and geodynamics. In: KovalenKo VI (ed) Tectonic Problems of Central Asia. World of Science, Moscow, pp 197-226

Yarmolyuk VV, KuZmin MI, ERnSt RE (2014) Intraplate geodynamics and magmatism in the evolution of the Central Asian Orogenic Belt. J Asian Earth Sci 93: 158-179

Zhang CL, Zou HB (2013) Permian A-type granites in Tarim and western part of Central Asian Orogenic Belt (CAOB): genetically related to a common Permian mantle plume? Lithos 172-173: 47-60

Zhang X, Zhang H, Tang Y, Wilde SA, Hu Z (2008) Geochemistry of Permian bimodal volcanic rocks from central Inner Mongolia, North China: implication for tectonic setting and Phanerozoic continental growth in Central Asian Orogenic Belt. Chem Geol 249: 262-281

Zhang X, Wilde SA, Zhang H, Zhai M (2011) Early Permian high-K calc-alkaline volcanic rocks from NW Inner Mongolia, North China: geochemistry, origin and tectonic implications. J Geol Soc, London 168: 525-543

Zhu YF, Sun SH, Gu LB, Ogasamara Y, Jiang N, Honwa H (2001) Permian volcanism in the Mongolian orogenic zone, northeast China: geochemistry, magma sources and petrogenesis. Geol Mag 138: 101-115 